鼻アレルギーのレーザー手術に関する研究

防衛医科大学校耳鼻咽喉科学講座

$$
\text { 中之坊学 }
$$




\title{
鼻アレルギーのレーザー手術に関する研究 \\ 中之坊学
}

\section{Laser Surgery for Allergic Rhinitis}

\author{
Manabu Nakanoboh \\ (National Defense Medical College)
}

Laser surgery, which is one type of surgical treatment for allergic rhinitis, was investigated basically and clinically.

Basically, we observed morphologic changes in nasal mucosa before and after laser surgery using an optical microscope and scanning electron microscope. The following results were obtained:

1) Hyperplasia of the mucous epithelium, thicking of the basement membrane, edema of the lamina propria mucosae, eosinophilic infiltration, enlargement of the nasal glands and dilatation of the sinusoidal capillary were noted in the allergic nasal mucosa before laser surgery.

2) After laser surgery, the nasal mucosa was covered with epithelium that was squamatized or cuboidal and/or columnar epithelium that was stratified. Granulation-like tissue or cicatricial tissue was found, but edema, eosinophilic infiltration and enlarged nasal glands all but disappeared in the lamina propria mucosae.

Between June 1986 and November 1993, laser surgery was performed clinically for 204 cases of refractory, perenial allergic rhinitis at the Out-patient Clinic, Department of Otolaryngology, National Defense Medical College Hospital. The following results were obtained:

1) Regarding short-term results (4 to 10 weeks after surgery), Laser surgery was effective in $70 \%$ (83 of 119 cases) for sneezing, $72 \%$ ( 120 of 166 cases) for nasal discharge, 91\% (185 of 204 cases) for nasal obstruction and $87 \%$ (177 of 204 cases) for nasal symptoms overall.

2) Regarding long-term results (more than 2 years after surgery), the short-term results had persisted in $81 \%$ ( 26 of 32 cases) for sneezing, $78 \%$ (32 of 41 cases) for nasal discharge, $76 \%$ (38 of 50 cases) for nasal obstruction.

From these results, we conclude that laser surgery was a useful surgical treatment for allergic rhinitis.

Key words : laser surgery, allergic rhinitis, morphologic changes 


\section{I. 緒 言 \\ II. 対 象 \\ III. 方 法}

1.レーザー手術

2. 鼻粘膜の観察

1 ) 肉眼的観察

2 ) 病理組織学的観察

3. 鼻腔通気度検査

4. 鼻粘膜粘膜固有層酸素分圧の測定

5. 手術成績の評価

1) 短期成績

2 ）長期成績

\section{N. 結 果}

1 . 鼻粘膜の術前術後の変化

1 ) 肉眼的所見
2 ) 病理組織学的所見

(1) 光学顕微鏡所見

（2）走査型電子顕微鏡所見

2. 鼻腔通気度の変化

3. 鼻粘膜粘膜固有層酸素分圧の変化

4. 手術成績

1 ）短期成績

2 ）長期成績

V. 考察

1 . 鼻アレルギーに対するレーザー手術の作用機

序について

2.レーザーの照射法について

3. 他の外科的治療法との比較について

4. 長期成績拉よび再発について

V. 結 語

た．著者らも1986年以来，200例を越える鼻アレルギー のレーザー手術を施行し，有効な臨床成績を扣さめてい る3)4). しかしながら，レーザー手術は，施設によって も方法が異なり，鼻アレルギーに対するその作用機序に ついては不明な点も多く，またレーザー手術の効果の持 続性についての報告が少ないのが現状である.

本論文では, 基礎的には, 光学顕微鏡および走查型電 子顕微鏡を用いレーザー手術前後の鼻粘膜の形態学的変 化を観察することに加えて, 鼻腔通気度および鼻粘膜粘 膜固有層酸素分圧を測定することにより，鼻アレルギー に対するレーザー手術の作用機序について考察し，臨床 的には，著者らの施行したレーザー手術の短期および長 期成績を詳細に分析して，鼻アレルギーの外科的治療法 の 1 つであるレーザー手術の有用性について検討を行っ た。

\section{II. 対 象}

対象は1986年 6 月より1993年11月の間に，防衛医科大 学校病院耳鼻咽喉科外来にて通年性鼻アレルギーと診断 され, 保存的治療により症状の改善がみられず, 特に強 度の鼻閉を訴えた，すなわち「鼻閉型」の難治性通年性 
鼻アレルギー患者204例である，ただし，鼻閉の主因が， 強度の鼻中隔弯曲症や鼻茸によると思われる症例は対象 より除外した．対象の内訳は図 1 亿示寸如く，男性 132 例，女性72例で，年齢は 8 歳〜 64 歳と広く分布している が，10歳台，20歳台の若年層が125例 (61.3\%) と多数を 占め, 15歳以下の小児例が44例 (21.6\%)含まれていた.

アレルギー性の診断は問診拈よび鼻鏡所見に加えて， 特異的 IgE 抗体検查 (radio-allergo-sorbent test ; RAST), 鼻粘膜誘発試験および鼻汁中好酸球テストの 3 項のうち 2 項目以上が陽性を示したものとした. 特異的 IgE 抗 体検查では，八ウスダストに対するRAST スコアが 2 以上の場合を陽性とし, 鼻粘膜誘発試験および鼻汁中好 酸球テストの判定は奥田の分類5)(表 1 ) によった。また,

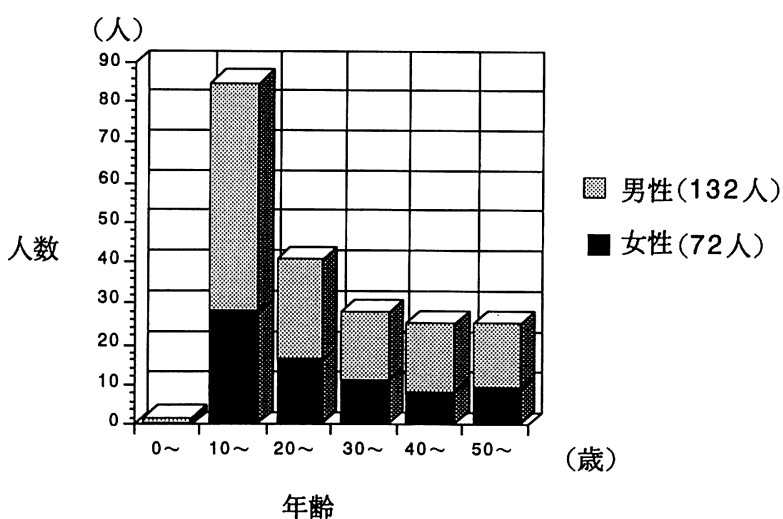

図 1 対象の性別・年齢別構成

患者年㱓は 8 歳〜 64歳と広く分布しているが， 10歳台， 20 歳台の若年層が125例 (61.3\%) と多数を占めている.

表 1 奥田の分類

くアレルギー性の診断＞

\begin{tabular}{|c|c|c|c|c|c|}
\hline 検查法 陽性度 & 世 & $H$ & + & \pm & - \\
\hline 鼻粘膜誘発試験* & $\begin{array}{l}\text { 症状 } 3 つ \\
\text { 特にくしゃみ } \\
6 \text { 回以上 }\end{array}$ & $\begin{array}{l}\text { 症状 3つ } \\
\text { くしゃみ } \\
5 \text { 回以下 }\end{array}$ & 症状 $2 つ$ & 症状 $1 つ$ & 0 \\
\hline 自汁中好酸球数 & 群在 & $\begin{array}{l}\text { \#と+の } \\
\text { 中間 }\end{array}$ & $\begin{array}{l}\text { 弱拡で目に } \\
\text { つく程度 }\end{array}$ & & 0 \\
\hline
\end{tabular}

* 症状 3つ: (1)くしゃみ発作・鼻疼痒感 (2)粘膜の腫脹蒼白 (3)水性分泌

<各鼻症状の程度 $>$

\begin{tabular}{|c|c|c|c|c|}
\hline 種 類 程 度 & m & $H$ & + & - \\
\hline $\begin{array}{c}\text { くしゃみ( } 1 \text { 日の } \\
\text { 平均発作回数) }\end{array}$ & 11 回以上 & $\sim 10$ 回 & $\sim 5$ 回 & 0 \\
\hline $\begin{array}{l}\text { 鼻 汁( } 1 \text { 日の } \\
\text { 平均擤鼻回数) }\end{array}$ & 11 回以上 & $\sim 10$ 回 & $\sim 5$ 回 & 0 \\
\hline 鼻 & $\begin{array}{l}\text { 鼻閉が非常に強く, } \\
\text { 口呼吸が } 1 \text { 日のうち } \\
\text { かなりの時間あり }\end{array}$ & $\begin{array}{l}\text { 鼻閉が強く, } \\
\text { 口呼吸が } 1 \text { 日 } \\
\text { のらち時々あり }\end{array}$ & $\begin{array}{l}\text { 口呼吸は全く } \\
\text { ないが鼻閉あり }\end{array}$ & なし \\
\hline
\end{tabular}

<鼻アレルギーの重症度 $>$

\begin{tabular}{|c|c|c|c|c|c|c|}
\hline \multirow{2}{*}{ 程 } & \multirow{2}{*}{ 度 } & \multicolumn{4}{|c|}{ くしゃみ発作または鼻汁(症状の強い方) } & \\
\hline & & $\mathrm{H}$ & $H$ & + & - & \\
\hline \multirow[t]{3}{*}{ 鼻 } & H & 重 & 重 & 重 & 重 & 重: 重 症 \\
\hline & $H$ & 重 & 中 & 中 & 中 & 中 : 中等症 \\
\hline & + & 重 & 中 & 軽 & 軽 & 軽: 軽 症 \\
\hline 閉 & - & 重 & 中 & 軽 & 無 & 無 : 無症状 \\
\hline
\end{tabular}


対象患者のくしゃ久，鼻汁，鼻閉の各鼻症状の程度およ

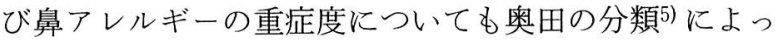
た。

\section{III. 方 法}

1.レーザー手術

専門外来(レーザー外来)を設け，全例，局所麻酔下に レーザー手術を実施した。麻酔は，4\%塩酸リドカイン と5000倍エピネフリンに浸したガーゼによる鼻内表面麻 酔と，10万倍エピネフリン含有 $0.5 \%$ 塩酸リドカインの 下鼻甲介粘膜下への局所浸潤麻酔によった。使用した レーザーは，1986年 6 月から1990年 5 月の97症例は $\mathrm{CO}_{2}$ レーザー(XANAR 社製 AMBULASE Model XAM-20) であり，1990年 6 月から1993年11月の107症例は KTP/
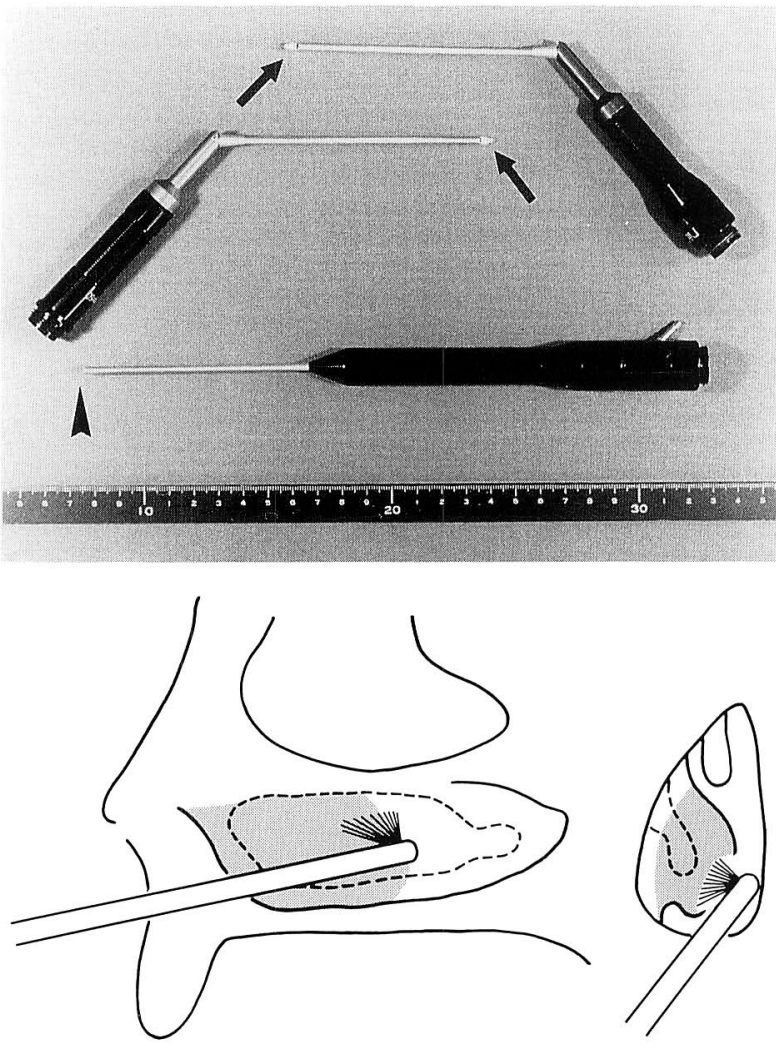

図 $2 \mathrm{CO}_{2}$ レーザーによる手術

上段：ハンドピース；側射型(矢印)と直射型(矢頭)

下段 : 手術手技シェーマ(側射型使用)

直射型で下鼻甲介前端を蒸散した後, 側射型で下鼻甲介 内側面を可及的広範囲にわたり後端まで蒸散し，下鼻甲 介容積の減量をはかった。
532 レーザー(LASERSCOPE 社製)である.

$\mathrm{CO}_{2}$ レーザーによる手術は，外径 $3 \mathrm{~mm}$ のアルミ製・ 中空のパイプ型ハンドピース (NIIC 社製)の直射型およ び側射型を用い，直射型で下鼻甲介前端を蒸散した後， 側射型で下鼻甲介内側面を可及的広範囲にわたり後端ま で蒸散することで，下鼻甲介容積の減量をはかった(図 2 ). 出力 $15 \mathrm{~W}$ (先端出力 $9 \mathrm{~W}$ ), 連続波で施行し, 一 側につき照射時間は10〜15分であった．

$\mathrm{KTP} / 532$ レーザーによる手術は，鼻科手術用ハンド ピース (LASERSCOPE 社製) の中に外径 $0.6 \mathrm{~mm}$ の導 光用石英ファイバーを通し，下鼻甲介粘膜に接触させな がら前端より後端にか外て切除することで，下鼻甲介容 積の減量をはかった（図 3 ). 先端出力 $7 〜 10 \mathrm{~W}$ ，連続波 で施行し，一側につき照射時間は約10分であった。
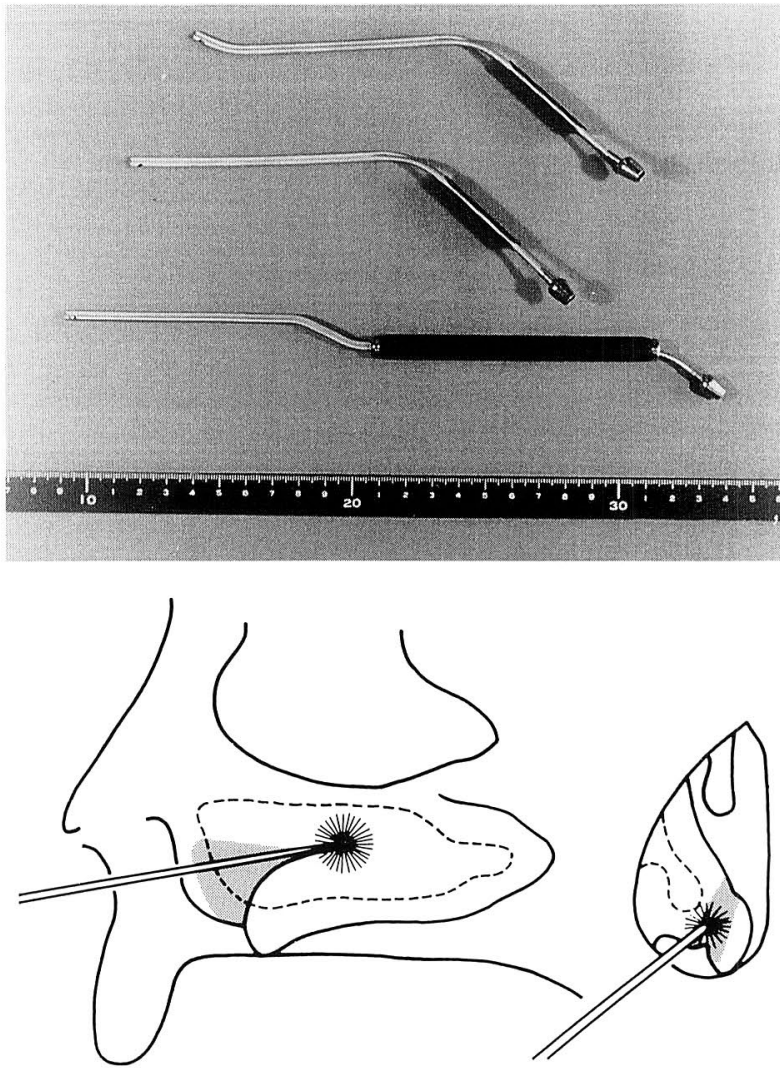

図 $3 \mathrm{KTP} / 532$ レーザーによる手術

上段：ハンドピース(曲と直)

下段: 手術手技シェーマ

石英ファイバー先端を下鼻甲介粘膜に接触させながら， 前端より後端にかけて切除し，下鼻甲介容積の減量をは かった。 
以上，いずれのレーザー手術も座位で，後鼻孔付近に 上咽頭への誤照射防止用の生食ガーゼを留置し, 眼球保 護の専用眼鏡を装着させ実施した。手術時間は約30分で あり，術後は鼻内タンポンを挿入せず帰宅させた。また， 内服薬，点鼻薬など他療法を併用することなく経過を観 察した.

\section{2. 鼻粘膜の観察}

1 ) 肉眼的観察

前鼻鏡所見として下鼻甲介粘膜の腫脹度, 色調, 鼻汁 量などの肉眼的観察を行い,ファイバースコープで術前 術後の鼻粘膜所見を記録した。術後観察は，肉眼的に鼻 粘膜の創傷治癒が萎浣了すると思われる頃，すなわ ち, $\mathrm{CO}_{2}$ レーザーでは $4 \sim 6$ 週目に, KTP/532 レーザー では $8 \sim 10$ 週目に行った。

\section{2 ) 病理組織学的観察}

$\mathrm{KTP} / 532$ レーザーで切除した初回手術時の下鼻甲介 粘膜標本 $(n=26)$, 同じく再手術時の下鼻甲介粘膜標本 $(\mathrm{n}=5)$ 打よび後述の短期成績の評価時 $(\mathrm{n}=21)$ と長期 経過時 $(n=3)$ に患者の同意を得て截除鈤子で採取した 下鼻甲介粘膜標本に沶いて, 術前術後の鼻粘膜の形態を 光学顕微鏡および走査型電子顕微鏡で観察した.

光学顕微鏡的には，採取した鼻粘膜を $10 \%$ ホルマリン で固定後パラフィン包埋し, 厚さ $3 \mu \mathrm{m}$ に薄切, へマト キシリン・エオジン染色を行い，鼻粘膜上皮扣よび粘膜 固有層の病理組織学的变化を中心に観察した.

走査型電子顕微鏡用標本は， $2.5 \%$ グルタールアルデ ヒドリン酸緩衝夜と $1 \%$ オスミニウム酸緩衝液で二重固 定し，上昇エタノール系列で脱水，酶酸イソアミル液に 置換した後, 液体炭素ガスによる臨界点乾燥を行い，イ オンスパッタリングで金をコーティングし作製した．走 査型電子顕微鏡(日本電子製，JSM-5200)を用い，鼻粘 膜表面微細構造の変化について観察した.

\section{3. 鼻腔通気度検査}

鼻腔通気の客観的評価として, 鼻腔通気度計(リオン 社製，SR-11）を用い，マスクによる anterior 法で鼻腔 抵抗值を測定した $(\mathrm{n}=45)$. 鼻腔内に多量の水様性鼻汁 がみられる時はこれを吸引除去してから実施した．鼻腔 抵抗值測定の基準点は $\mathrm{p}=100$ pascal とし，吸気時総合 鼻腔抵抗值を術前と短期成績評価時（術後 $4 \sim 10$ 週目）で 比較して，鼻閉の他覚的改善度について検討した．鼻腔 抵抗值の評価として一般化されたものはないが，今回自 験例では，鼻腔抵抗值による鼻閉の尺度として目井6に
よる尺度を目安とした。

\section{4 . 鼻粘膜粘膜固有層酸素分圧の測定}

一部の症例 $(n=16)$ において，術前と短期成績評価時 (術後 $4 \sim 10$ 週目) 飞鼻粘膜粘膜固有層酸素分圧(以下, 鼻粘膜酸素分圧)を測定した。生体組織内酸素分圧連続 測定装置(インターメディカル社製， $\left.\mathrm{PO}_{2}-100 \mathrm{DW}\right) を$ 用い，ニードル型の電極を臥位で患者下鼻甲介粘膜の前 端に深さ約 $1 \sim 2 \mathrm{~mm}$, 無麻酔で刺入後, 患者が精神的 に安定し，かつ測定装置自体が安定するまで約10分間待 ち実施した。この組織酸素分圧測定は, 電気化学現象を 利用したもので， $\mathrm{O}_{2}+2 \mathrm{H}_{2} \mathrm{O}+4 \mathrm{e}^{-} \rightarrow 4 \mathrm{OH}^{-}$といら酸化 還元反応により組織内の $\mathrm{O}_{2}$ 拡散電流を生じさせ, これ を測定し酸素分圧を算出する酸素電極法によった．対照 は，鼻疾患を有さない正常者 $(\mathrm{n}=12)$ の鼻粘膜酸素分圧 とした.

\section{5. 手術成績の評価}

1) 短期成績

短期成績の評価は，前述の術後鼻粘膜の肉眼的観察時 $\left(\mathrm{CO}_{2}\right.$ レーザーでは 4〜 6 週目， $\mathrm{KTP} / 532$ レーザーでは $8 \sim 10$ 週目)に併せて行った $(\mathrm{n}=204)$. 各鼻症状の術後 改善度は, 鼻アレルギー日記に基づく患者の自覚症状の 变化を, 消失 (症状消失), 著明改善 ( 2 段階改善), 改善 ( 1 段階改善)，不变，悪化の 5 段階に分け評価した。 た，レーザー手術による全般改善度としては，各鼻症状 別の改善度, 鼻アレルギーの重症度の変化に加えて前鼻 鏡所見, ファイバースコープ所見なども総合して, 消失, 著明改善, 改善, 不変, 悪化の 5 段階に分け評価し, 改 善以上をレーザー手術の有効例とした.

\section{2 ) 長期成績}

1986年 6 月〜1991年 3 月の間にレーザー手術を施行し, その短期成績(術後 $4 \sim 10$ 週目) が有効であり，術後 2 年 以上経過する鼻アレルギー患者96例を対象にアンケート 調査を実施した。アンケートでは，短期成績評価時の鼻 症状之現在の鼻症状の比較を中心に質問した(図 4 ).

アンケート調查を実施した96例のうち，50例より回答 が得られた(回収率52\%)。これら50例のアンケート結果 を分析し，レーザー手術の効果の持続性や再発などの長 期成績について検討した. 
このアンケート調查は、当科で鼻アレルギーのレーザー手術を受けられ、2年以上経過 された方を対象に行っております。今後の治療の参考にしたいと考えておりますので、御 協力のほど宜しくお願い致します。

1. あなたは、19 年 月 日に当科で鼻アレルギーのレーザー手術を受けておられ ます。

2.レーザー手術後＼cjkstart週目であなたの症状は下記のように改善したものと思います。

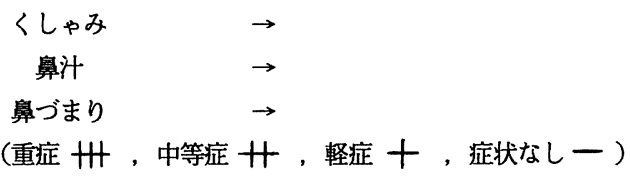

3. その後、来院していただいておりませんが、手術後 週目之珼在を些べ、鼻の調子 はいかがでしょうか。該当するものに○をつけてください。

\begin{tabular}{l|l|l|l} 
& くしゃみ & 鼻汁 & 鼻づまり \\
\hline $\begin{array}{l}\text { “さらによくなった” } \\
\text { “かわらず”(手術後の良い状態が続いている) } \\
\text { “わるくなった”（手術前と同じ状態に戻った) }\end{array}$ & & & \\
\end{tabular}

4. 3で“わるくなった” と答えた方にお尋ねします。調子の良い期間は手術後どのくら い続きましたでしょうか。

$$
\text { くしゃみ 約( )力月 鼻汁 約( )力月 鼻づまり 約( )カ月 }
$$

5. 現在、何か他の治療を受けていますか。受けていれば具体的に。

$$
\text { 受けていない 受けている( ) }
$$

6. 機会があればもう一度この手術を受けたいと思いますか。
はい
いいえ
わからない

7. その他お気付きのこと、御感想などありましたら、お書き下さい。

図 4 アンケート内容

\section{N. 結果}

1. 鼻粘膜の術前術後の変化

1) 肉眼的所見

鼻粘膜の肉眼的所見では，術前は，ほぼ全例に蒼白で 腫脹した下鼻甲介に水様性鼻汁が付着する典型的な鼻ア レルギーの所見がみられた．術直後は，下鼻甲介表面に 炭化した黒色の痂皮と凝血塊が付着していた．その後 1 〜 週は下鼻甲介表面にフィブリンの析出物と滲出液が みられたが，これらは次第に減少し痂皮化していった. さらに短期成績評価時(術後 $4 \sim 10$ 週目)には，ほとんど
の症例で痂皮は脱落し上皮化はほぼ完了していたが，鼻 粘膜表層が淡紅色で軽度凹凸のある肉芽様組織で被覆さ れている症例（図 5 ) と，比較的白色調で表面平滑な症痕 様組織で被覆されている症例（図 6 )に大別された。いず れの場合も，下鼻甲介容積は著明に減じられ，水様性鼻 汁は減少していた。

2 ) 病理組織学的所見

(1) 光学顕微鏡所見

術前の患者鼻粘膜には，鼻粘膜上皮の所見として，杯 細胞の増生が31\%(26例中 8 例)に，基底細胞の増生が27 


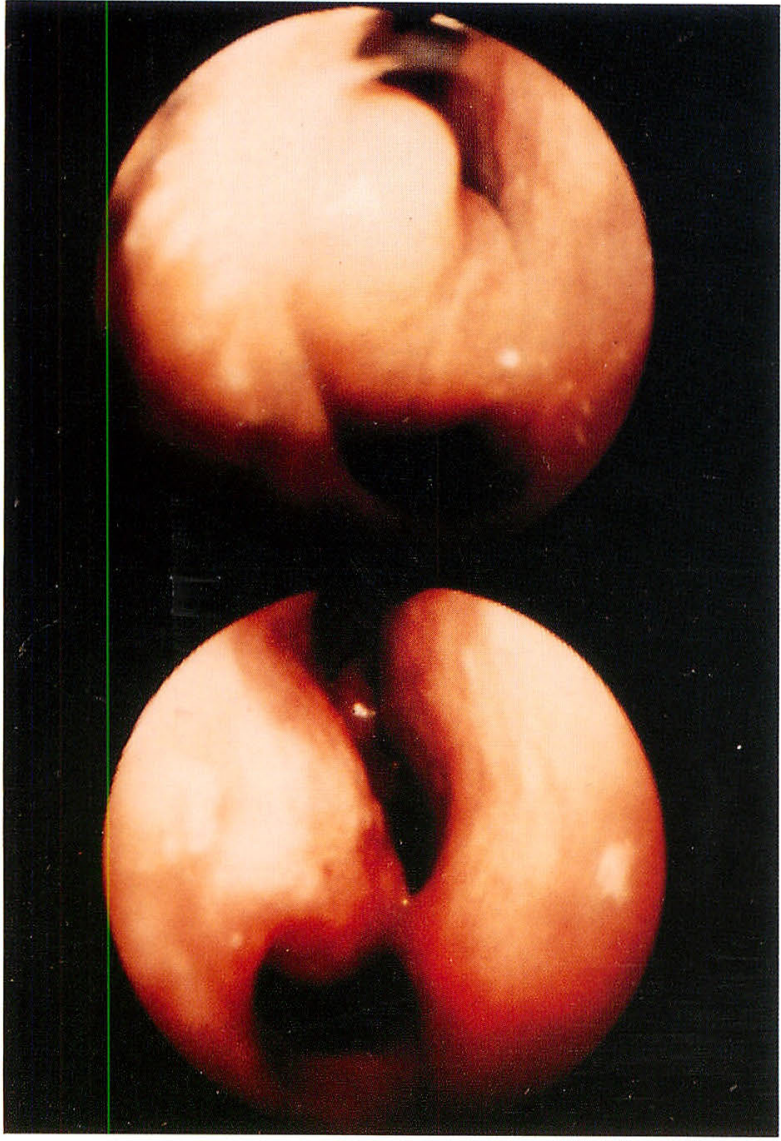

図 5 術後鼻粘膜が肉芽様組織で被覆された症例 上段：術前

鼻粘膜は水様性鼻汁が付着し高度に腫大してい る.

下段 : 術後 8 週目

鼻粘膜表面は淡紅色で軽度凹凸のある肉芽様組織 で被覆され，下鼻甲介容積は著明に減少している。

$\%$ (26例中 7 例) に，基底膜の肥厚が $46 \%$ (26例中 12 例)に みられた。立た，粘膜固有層の所見として，浮腫が 81 $\%$ (26例中 21 例)，好酸球浸潤が50\%(26例中 13 例)，鼻粘 膜分泌腺の増大が $85 \%$ (26例中22例)，洞様血管の拡張が $65 \%(26$ 例中17例) と，それぞれ高率にみられた。肉眼的 に浮腫状変化の強いものほど, 高度の粘膜固有層の浮腫 と洞様血管の拡張がみられた(図 7 ).

短期成績評価時(術後 $4 \sim 10$ 週目)には上皮化は完了し て扣り，扁平上皮化生した形態をとる上皮で覆われてい たもの $52 \%$ (21例中 11 例)，立方ないし円柱状の細胞が重 層化した形態をとる上皮で覆われていたもの29\%(21例 中 6 例), と 8 割以上の症例は術前の多列線毛円柱上皮

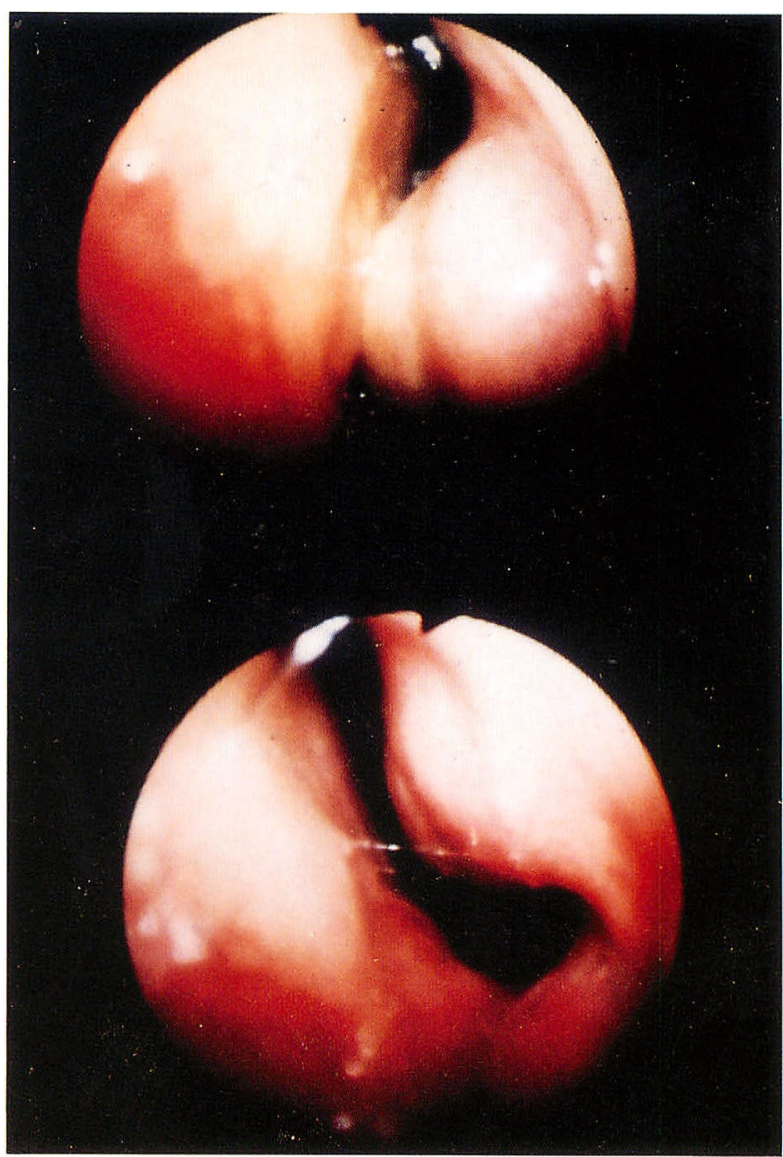

図 6 術後鼻粘膜が瘵痕様組織で被覆された症例 上段：術前 蒼白で著明に腫脹した下鼻甲介がみられる。

下段 : 術後 9 週目 鼻粘膜表面は比較的白色調で表面平滑な瘷痕様組 織で被覆され，総鼻道は十分に開大されている.

と異なる形態の上皮で覆われていた（図 8 )。また，粘膜 固有層は，毛細血管の増生とコラーゲン線維の新生を伴 ら多数の線維芽細胞集団，すなわち肉芽様組織に置換さ れていたもの67\%(21例中14例)，血管に乏しく主として コラーゲン線維のみからなる痗痕様組織に置換されてい たもの24\%(21例中 5 例)であった（図 9 )。いずれにせよ， 術前同層にみられた浮腫，好酸球浸潤，増大した鼻粘膜 分泌腺などはほとんど消失していた。

長期成績評価時(術後 2 年以上経過)に効果の持続して いた症例(非再発例) に扣いては，術後 $4 \sim 10$ 週目の所見 とほぼ同様に，重層扁平上皮化生した形態をとる上皮と， 主としてコラーゲン線維からなる瘢痕様組織に置換され 



図 7 術前患者鼻粘膜の光学顕微鏡所見

上段：鼻粘膜上皮には，杯細胞(矢印)扣よび基底細胞 (太 矢印)の増生之基底膜 (*印)の肥厚がみられる。

下段：鼻粘膜固有層には, 浮腫, 好酸球の浸潤, 鼻粘膜 腺 (矢頭)の増大, 洞様血管(矢印)の拡張などがみ

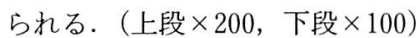

た粘膜固有層がみられた（図10)。一方，長期成績評価時 に効果の消失していた症例(再発例)では，粘膜上皮は本 来の多列円柱線毛上皮であり，多数の杯細胞がみられ， 粘膜固有層には浮腫, 好酸球の浸潤, 鼻粘膜分泌腺の增 大など典型的な鼻アレルギーの粘膜所見が再度みられた (図11).

（2）走査型電子顕微鏡所見

正常鼻粘膜に捻いて, 表面からみ只る細胞は, 線毛細 胞と主として杯細胞と考号られる無線毛細胞の 2 種類で あり，そのほとんどは線毛細胞である(図12)。

鼻アレルギーの下鼻甲介粘膜表面微細構造の変化は, 線毛細胞の減少と杯細胞の増加として観察された. 線毛

図 8 術後短期の鼻粘膜上皮光学顕微鏡所見

上段：扁平上皮化生した形態をとる上皮で覆われていた 症例(術後10週目)

下段：立方ないし円柱状細胞が重層化した形態をとる上 皮で覆われていた症例(術後 9 週目)（×200）

細胞数の減少のみならず, 線毛自体の減少, 短小化とい った変化もみられた. 変化の程度は, 注涪正常のものか ら, 線毛細胞が極端に減少しほとんどが杯細胞に置換さ れているようなものまで様々であった(図13). 肉眼的に 浮腫状変化の強いもの活ど, このような变化も高度であ った.

短期成績評価時(術後 4 〜 10週目) に有効であった症例 の再生鼻粘膜上皮には，線毛細胞や杯細胞はみられず, 扁平上皮で覆われていた。 また, 扁平上皮に上る再生過 程と思われる所見も得られた(図14).

長期成績評価時(術後 2 年以上経過) 飞効果の消失して いた症例(再発例)の再手術時の標本を観察すると，その 

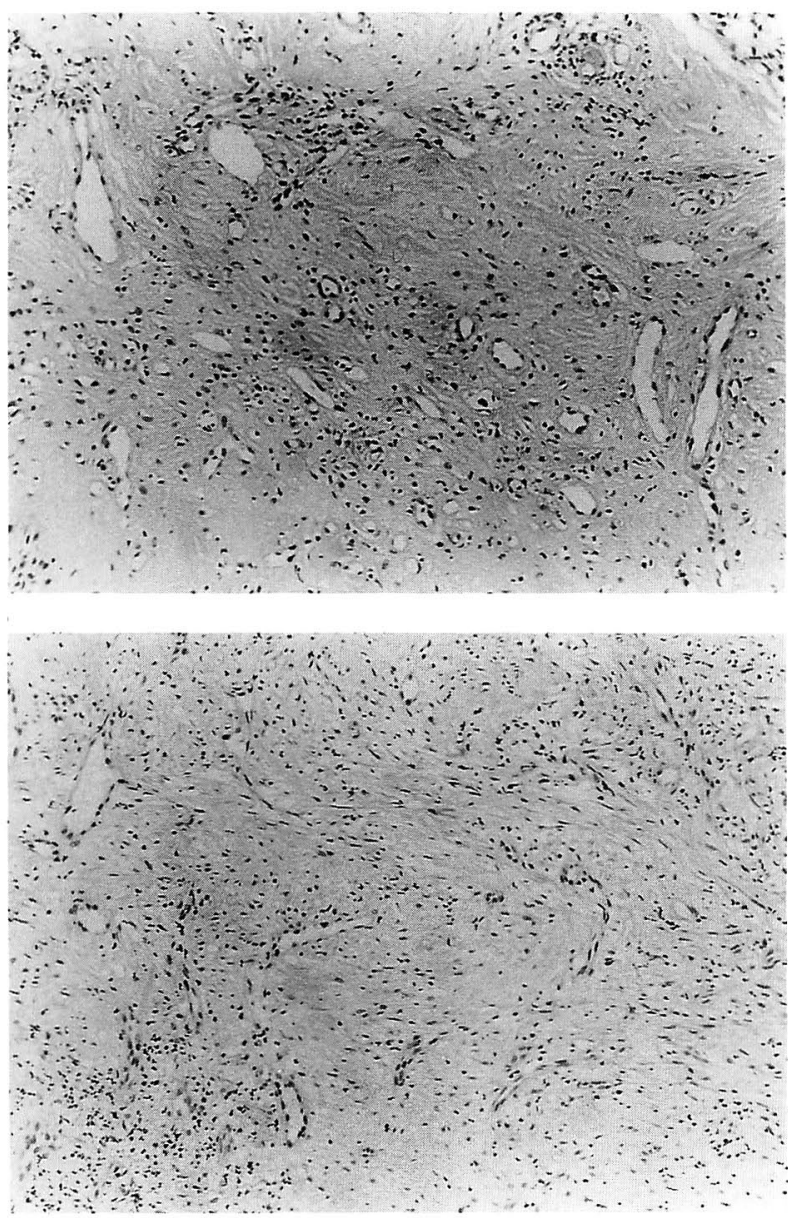

図 9 術後短期の鼻粘膜粘膜固有層光学顕微鏡所見

上段 : 肉芽様組織に置換されていた症例(術後 8 週目) 毛細血管の増生と多数の線維芽細胞がみられる。

下段：痗痕様組織に置換されていた症例(術後 8 週目) 血管に乏しく主としてコラーゲン線維がみられる。 $(\times 100)$

光顕所見同様，鼻粘膜上皮は扁平上皮ではなく，線毛細 胞と杯細胞からなる呼吸上皮であった。また，正常鼻粘 膜上皮と比べると, 線毛細胞の減少と杯細胞の増加がみ られた(図15)。長期成績評価の時点で効果が持続してい る症例に関しては，鼻粘膜上皮の走査型電子顕微鏡によ る観察は行っていない.

以上, レーザー手術前後の鼻粘膜の病理組織学的変化 を表 2 にまとめた。

\section{2. 鼻腔通気度の変化}

術前術後に鼻腔通気度を測定しえた45症例の鼻腔抵抗 值の変化を図16に示した。術前は，鼻腔抵抗値が 0.75

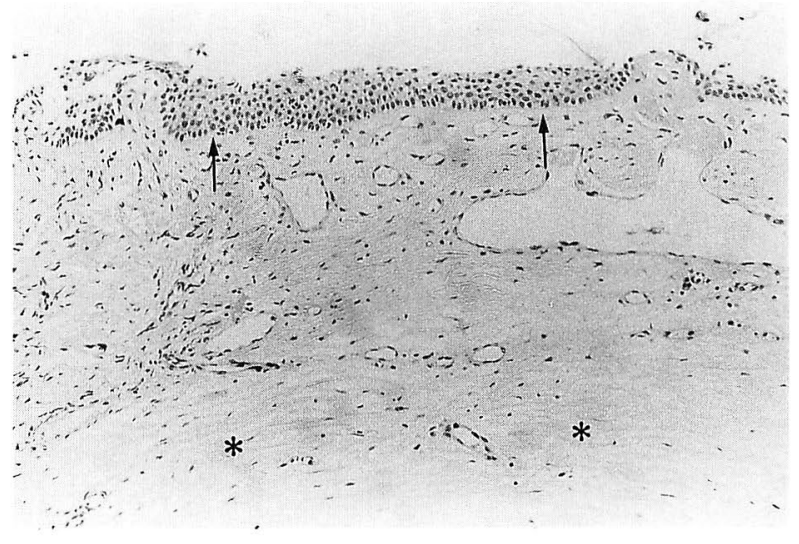

図10 術後46力月目の鼻粘膜光学顕微鏡所見 (非再発例)

重層扁平上皮化生した形態をとる上皮(矢印) と，主とし てコラーダン線維からなる瘢痕様組織 (*印) に置換され た粘膜固有層がみられる。( $\times 33)$

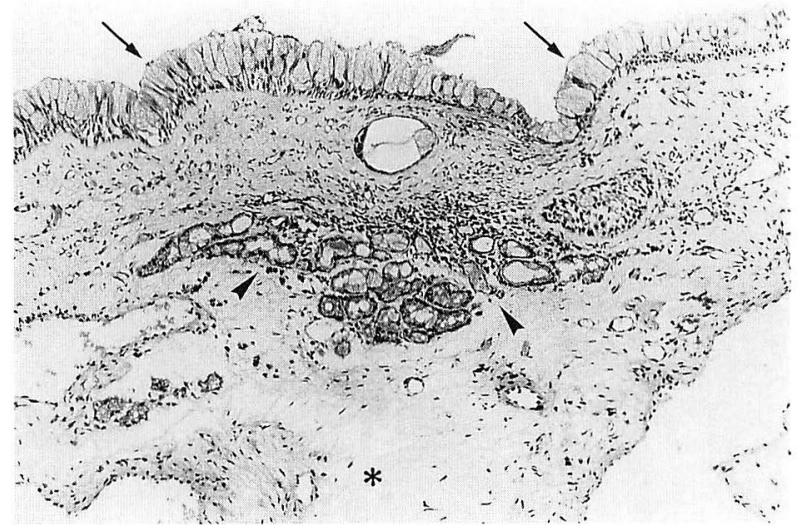

図11術後54力月目の鼻粘膜光学顕微鏡所見(再発例)

粘膜上皮は多列円柱線毛上皮であり, 多数の杯細胞がみ られ (矢印), 粘膜固有層には浮腫 (*印), 好酸球の浸潤, 鼻粘膜腺の増大 (矢頭)など典型的な鼻アレルギーの所見 が再度みられる. $(\times 33)$

$\mathrm{pascal} / \mathrm{cm}^{3} / \mathrm{sec}$ 以上の高度鼻閉例が $27 \%$ (45例中 12 例)， $0.50 \sim 0.75 \mathrm{pascal} / \mathrm{cm}^{3} / \mathrm{sec}$ の中等度鼻閉例が $29 \%$ (45例 中13例)であったが，術後は， $0.25 \sim 0.50 \mathrm{pascal} / \mathrm{cm}^{3}$ $/ \mathrm{sec}$ の軽度鼻閉例が $67 \%$ (45例中 30 例)， $0.25 \mathrm{pascal} /$ $\mathrm{cm}^{3} / \mathrm{sec}$ 以下の正常例が $31 \%$ (45例中 14 例) であった. 全 体として, 術前の抵抗值は $0.60 \pm 0.27$ (mean \pm S.D.) $\mathrm{pascal} / \mathrm{cm}^{3} / \mathrm{sec}$ であり, 術後のそれは $0.30 \pm 0.09$ pas$\mathrm{cal} / \mathrm{cm}^{3} / \mathrm{sec}$ と有意な減少を示した $(\mathrm{p}<0.01, \mathrm{t}$ 検定 $)$. 


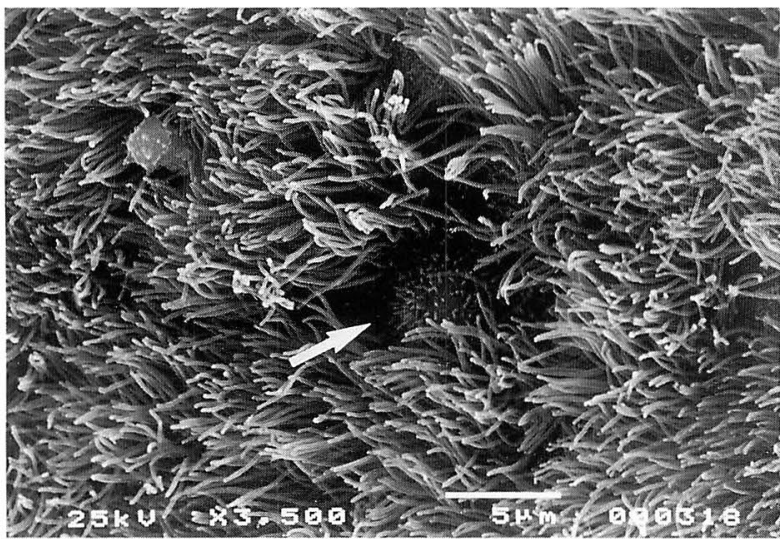

図12正常鼻粘膜の走査型電子顕微鏡所見

正常鼻粘膜に扮いて，表面から見える細胞は，主として 線毛細胞と杯細胞(矢印)の 2 種類であり，そのほとんど は線毛細胞である。
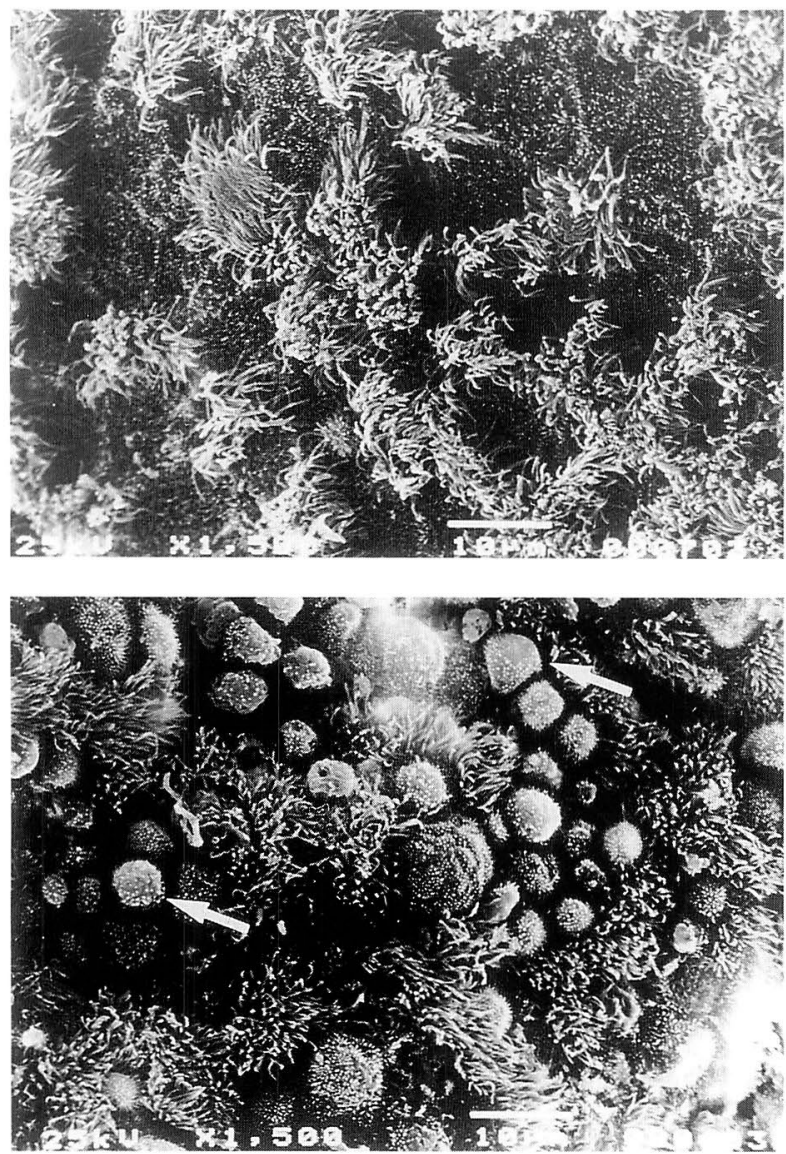

図13 術前患者鼻粘膜の走査型電子顕微鏡所見

上段 : 線毛細胞の減少が散見される軽度変化例

下段：杯細胞(矢印)の増加や線毛自体の減少，短小化も 目立つ高度変化例
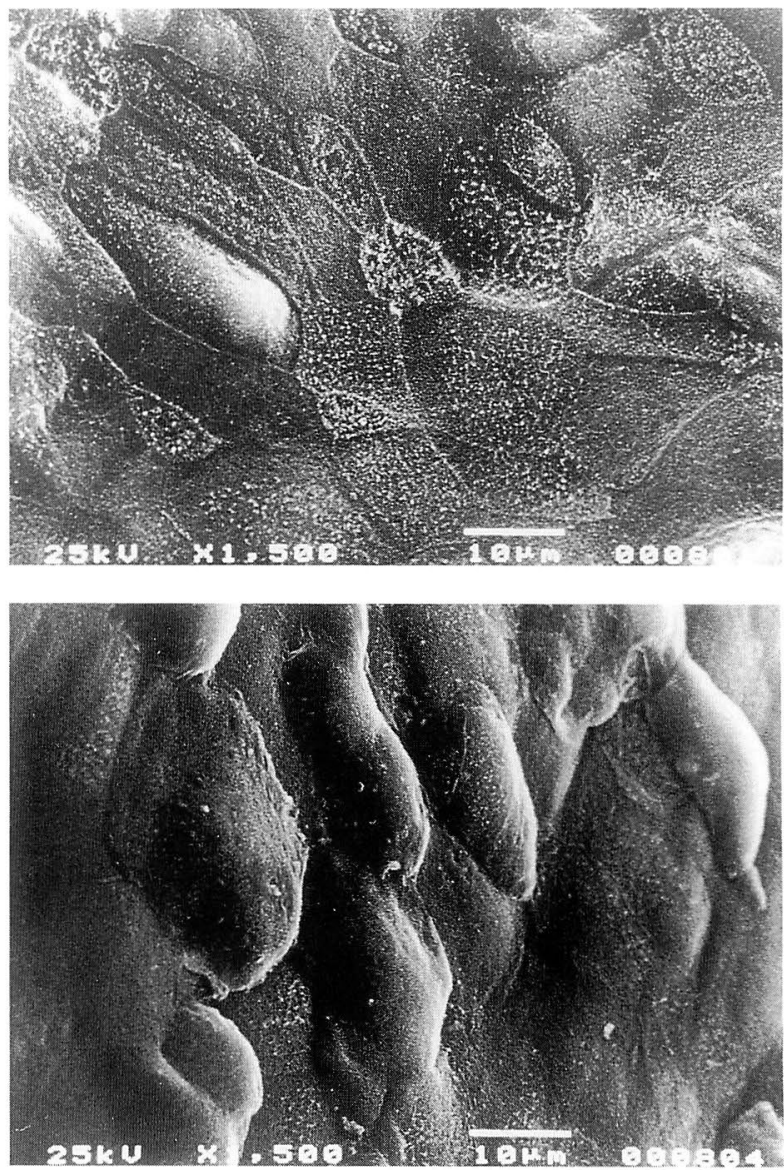

図14術後短期(有効例)の鼻粘膜走査型電子顕微鏡所見

上段 : 再生粘膜は, 扁平上皮で覆われている(術後 10 週).

下段：扁平上皮による再生過程と思われる所見もみられ た(術後 8 週)

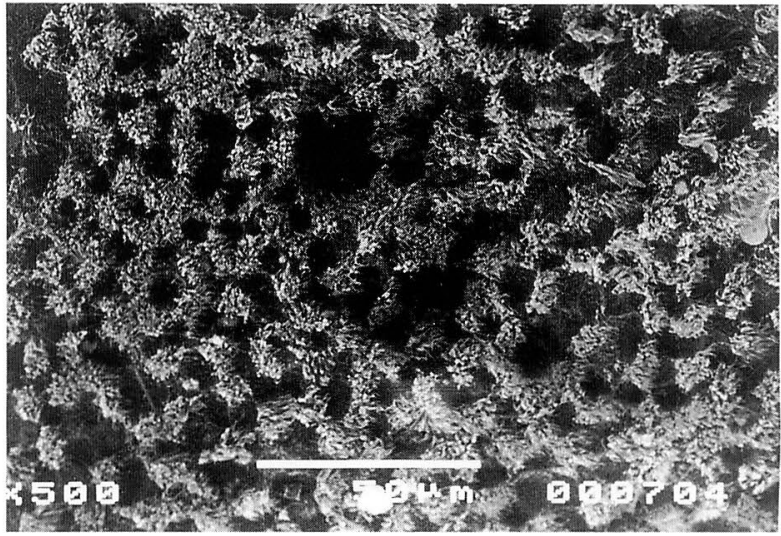

図15 術後38力月目の鼻粘膜走査型電子顕微鏡所見 (再発例)

粘膜上皮は扁平上皮ではなく呼吸上皮であり，線毛細胞 の減少と杯細胞の増加がみられる。 
表 2 鼻粘膜の病理組織学的変化

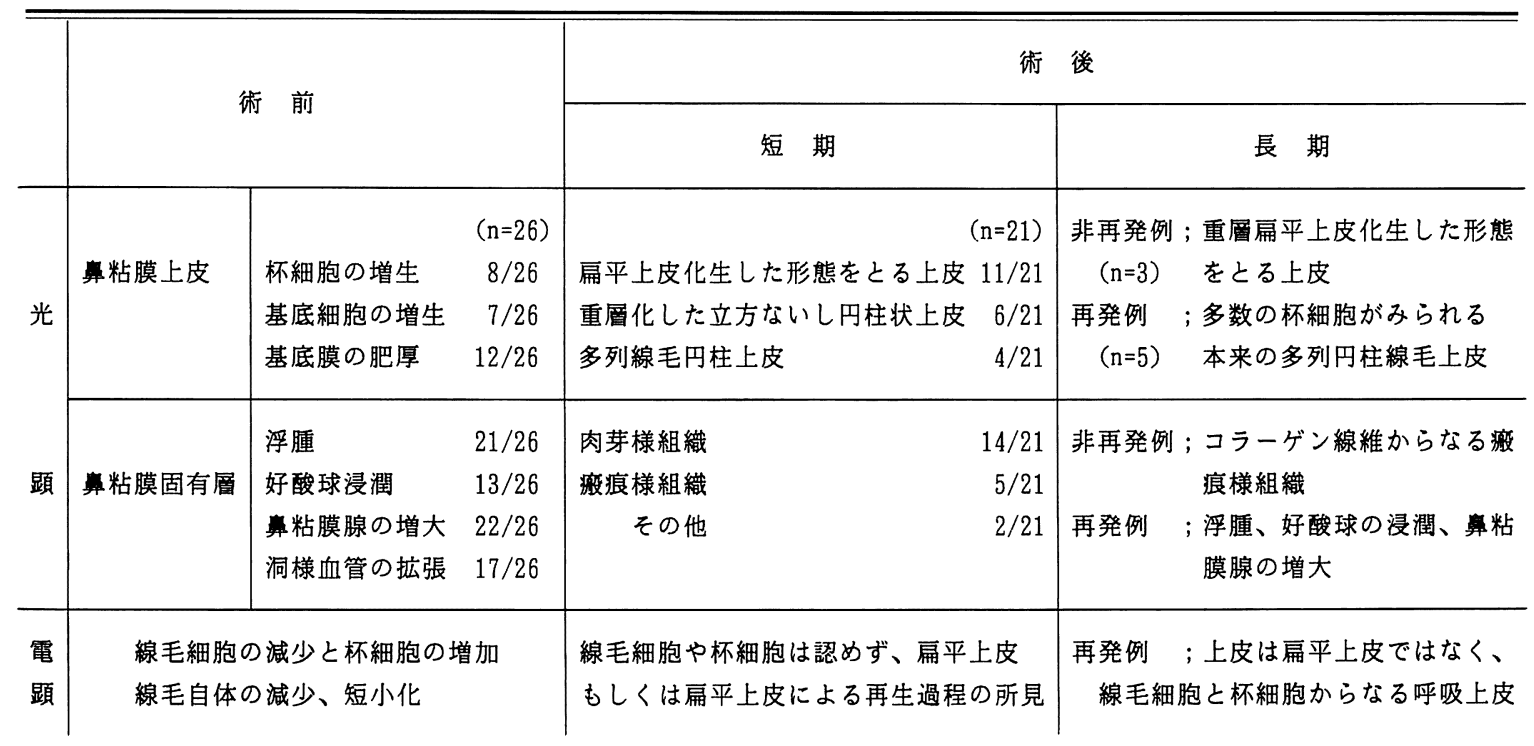

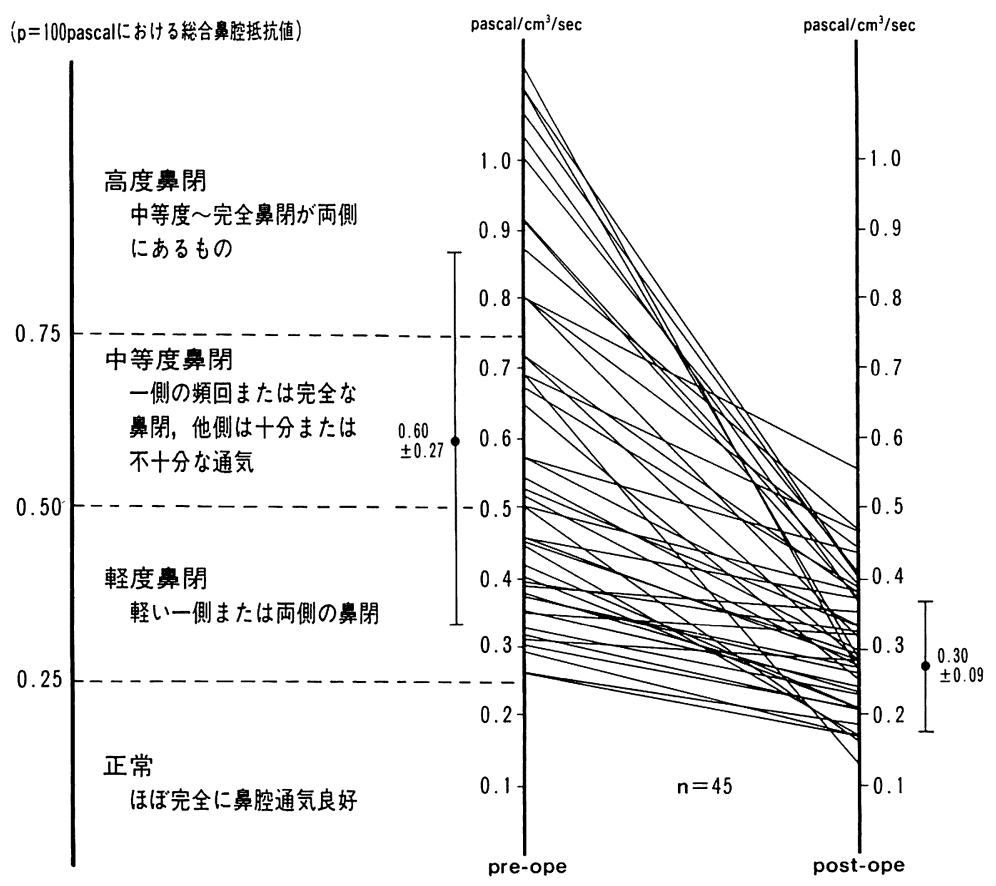

図16 鼻腔抵抗値の変化

図左 : 鼻腔抵抗值による鼻閉の尺度 (臼井信郎：1992 $2^{6)}$ より改变)

図右 : 術前術後の患者の鼻腔抵抗值の変化 $(\mathrm{n}=45)$

術後番腔抵抗值は有意に減少した $(\mathrm{p}<0.01, \mathrm{t}$ 検定 $)$. 


\section{3. 鼻粘膜粘膜固有層酸素分圧の変化}

対照として測定した正常者 12 例の鼻粘膜酸素分圧值は

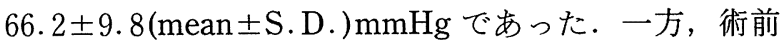
術後に測定し得た 16 症例の患者鼻粘膜酸素分圧値は，術

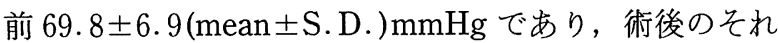
は64.4士16.4 mmHg であった(図17). 正常対照群，術 前，術後の 3 者間に有意差はみられなかった( $\mathrm{t}$ 検定).

\section{4. 手術成績}

1) 短期成績

鼻アレルギー日記に基づく患者の自覚症状の改善度は, 図18の如くで，各鼻症状別では，〈しゃみに対して70 $\%$ (119例中83例), 鼻汁に対しては72\%(166例中 120 例), 鼻閉に対して91\%(204例中185例)の有効率が得られた. 全般改善度では $87 \%$ (204例中177例)に有効であった。特 に鼻閉に関しては，消失50\%(204例中102例)，著明改善 $22 \%$ (204例中46例) といら極めて良好な成績が得られ， くしゃみ, 鼻汁に比べ有意に高い有効率が得られた $(\mathrm{p}<$ $0.01, \mathrm{H}$ 検定).

\section{2 ）長期成績}

アンケート調査で回答が得られた 50 例の術後経過期間 は, 最短 26 力月, 最長 62 力月 (平均 42.4 力月)で, らち 38 例は $\mathrm{CO}_{2}$ レーザー手術施行例であり，12例は $\mathrm{KTP} / 532$ レーザー手術施行例であった．短期成績評価時の鼻症状 と現在の鼻症状を比較したアンケート結果を図19に示し た．図中“さらによくなった”と“かわらず”を加えた 効果持続例(非再発例)は, 各鼻症状間に差はなく, くし やみで81\%(32例中26例)，鼻汁で78\%(41例中32例)，鼻 閉で76\%(50例中38例)であった。これら非再発例では， レーザー手術後は内服薬, 点鼻薬などの併用療法を受け ることなく経過していた。しかしながら各鼻症状とも 19 〜24\%の再発がみられ，再発までの期間は，くしゃみに 関しては，6 カ月未満50\%(3/6)，6１2力月50\%(3/6), 鼻汁に関しては， 6 力月未満 $33 \%(3 / 9) ， 6 \sim 12$ 力月 45 $\%(4 / 9) ， 12$ 力以上 $22 \%(2 / 9)$, 鼻閉に関しては 6 力月 未満 $25 \%(3 / 12) ， 6 \sim 12$ 力月 $42 \%(5 / 12) ， 12$ 力以上 33 \%(4/12)であった.
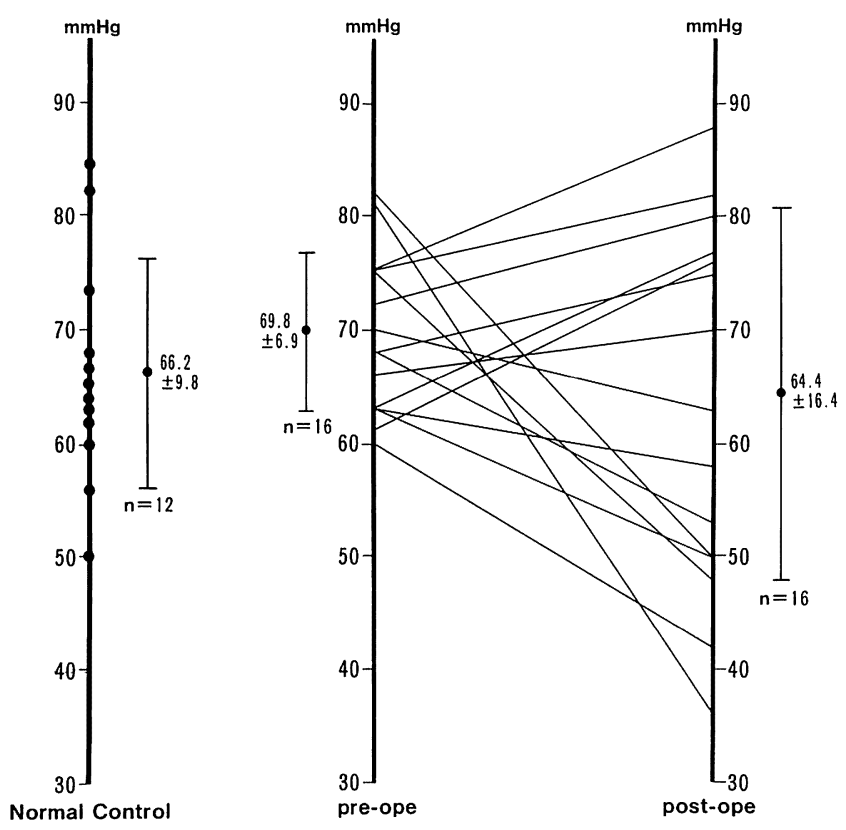

図17 鼻粘膜粘膜固有層酸素分圧の変化

図左: 正常対照群 $(n=12)$ の鼻粘膜粘膜固有層酸素分 圧

図右 : 術前術後の患者 $(n=16)$ の鼻粘膜粘膜固有層酸 素分圧の变化

正常対照群, 術前, 術後の 3 者間に有意差はなかった ( $\mathrm{t}$ 検定). 

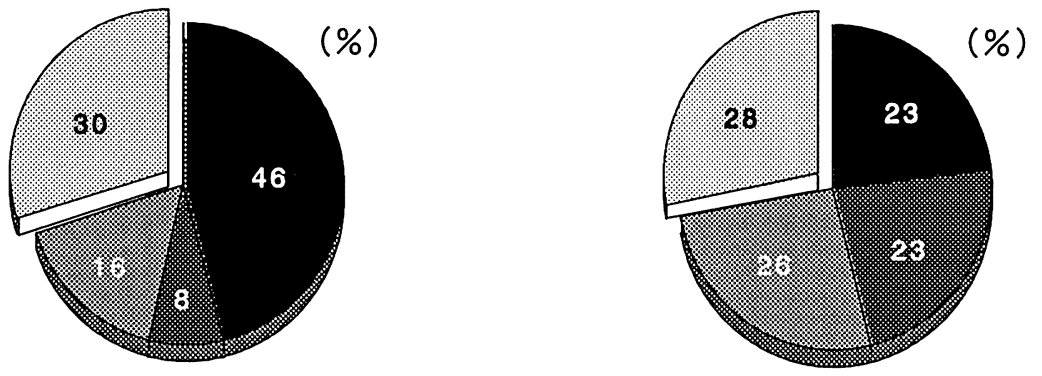

くしゃみ $(n=119)$

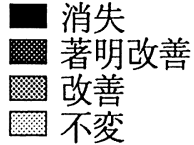

鼻汁 $(n=166)$

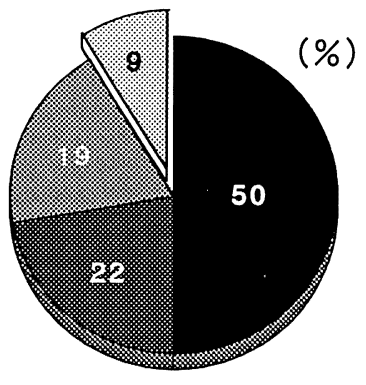

鼻閉 $(n=204)$

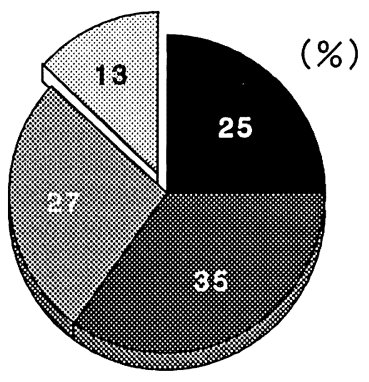

全般改善度（ $n=204 ）$

図18レーザー手術の短期成績

各鼻症状別の有効率(改善以上)は，〈しゃみ $70 \%$, 鼻汁 $72 \%$, 鼻閉 $91 \%$ であった。

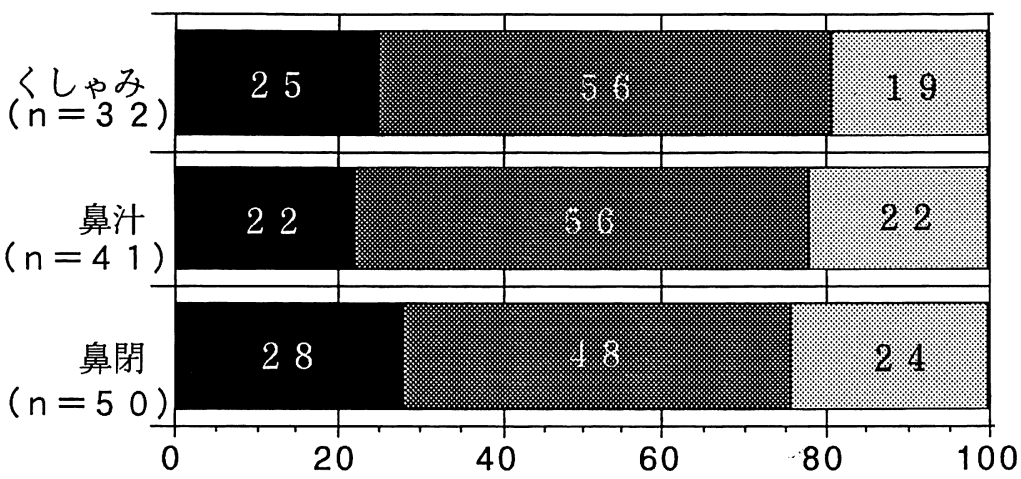

(\%)
“さらによくなった”
“かわらず”（術後の良い状態が続いている）
“】】. “わるくなった”（術前と同じ状態に戻った）

図19 レーザー手術の長期成績

50 例の術後経過期間は平均 42.4 カ月であり, くしゃみは $81 \%$, 鼻汁は $78 \%$, 鼻閉は $76 \%$ の症例で効果が持続 (“さらによくなった”もしくは“かわらず”) していた. 


\section{V. 考察}

1 . 鼻アレルギーに対するレーザー手術の作用機序に ついて

外科的治療法の 1 つであるレーザー手術が，いかなる 作用機序をもって鼻アレルギー症状を消失もしくは軽減 させるのか，以下に検討を加えた。

第 1 点として, レーザーにより蒸散，切除された下鼻 甲介容積の絶対的な減少があげられ，これにより鼻閉が 軽減するものと考えられる。この点については, 術前術 後の前鼻鏡所見でも明らかであるが，鼻腔通気度検査の 結果もまたそれを裏付けている.

鼻腔通気度検査は, anterior 法と posterior 法に大別 され，前者は，完全閉塞している鼻腔では測定不能とな る，両側同時に実測できない，などの欠点はあるものの， 簡便に測定できるため現在標準法とされている7)。また， 鼻腔通気度検査では，一定の圧基準点に打ける抵抗值を 比較する必要があり，国際的には $\mathrm{p}=150$ pascal を基準 点とすることが多い傾向にあるが8)，国内的には $\mathrm{p}=100$ pascal を基準点とすることが多い6). そこで今回われわ れは，マスクによる anterior 法を用い，基準点を $\mathrm{p}=$ 100 pascal とし，吸気時総合鼻腔抵抗值を測定した。 そ の結果, 大多数の症例で自覚的な鼻閉の改善度と鼻腔抵 抗值の変化は良く一致し，この鼻腔通気度検査が鼻閉の 改善を十分に反映するものと考えられた，ただし，少数 例で鼻閉の改善度と鼻腔抵抗值の変化が必ずしも一致し ないことがあり，その要因としては，鼻閉感は多分に感 覚的なもので閾值に個人差があること, 鼻汁の存在や nasal cycleによって修飾されること，などが考えられ る。

第 2 点として，鼻粘膜上皮に存在する杯細胞および鼻 粘膜固有層に存在する鼻粘膜分泌腺の減少があげられる. この点は, レーザー手術前後の鼻粘膜の光学顕微鏡所見 の変化から明らかであり，これにより水様性鼻汁の軽減 がもたらされるものと考觉られる。

第 3 点として，鼻粘膜上皮の重層扁平化によるアレル ギー反応の抑制があげられる．術後再生した鼻粘膜上皮 は本来の多列線毛上皮とは異なり，扁平上皮化生した形 態をとる上皮や立方ないし円柱状の細胞が重層化した形 態をとる上皮となって扣り，これにより大気中の抗原が 粘液層に吸収され鼻粘膜に付着したとしても，上皮下に 侵入することを困難にし以後のアレルギー反応の進行が 抑制されるものと考えられる. $\mathrm{CO}_{2}$ レーザー手術を施
行した福武ら ${ }^{9)}$ は，術後 1 年間良好に経過した 34 例の鼻 粘膜誘発試験の域值と鼻汁中好酸球の変化を検討した結 果, 術後は誘発試験の域值上昇と好酸球の減少がみられ, レーザー手術による鼻粘膜表層の組織学的な変化が抗原 抗体反応を抑制する，と結論づけている。 また，同様に $\mathrm{CO}_{2}$ レーザー手術を施行した川村ら ${ }^{10)}$ は，手術前後に 扣ける抗原誘発による鼻腔洗浄液中の ECP (eosinophilic cationic protein)の増減を検討したところ, 症状改善群 では ECPが減少し，レーザー手術による効果発現機序 の 1 つとして，鼻粘膜上皮の扁平上皮化生に伴ら化学伝 達物質の放出抑制をあげて扣り，これら両者の報告は， われわれの考察と一致する。

第 4 点として，鼻粘膜固有層の疲痕化があげられる. レーザー手術後の創傷治癒過程において, 浮腫状の鼻粘 膜固有層は，多数の新生血管之線維芽細胞からなる肉芽 様組織を経て，長期的には密な膠原線維からなる瘢痕様 組織に置換されるものと考えられ，これにより抗原暴露 時も鼻粘膜固有層に浮腫が生じにくくなり鼻閉が軽減す る。

今回われわれは, 鼻粘膜の腫脹や色調に多分に関与す るとされる鼻粘膜血行動態について検討する目的で，一 部の症例に括いて鼻粘膜酸素分圧を測定した。その結果, 正常群と術前鼻アレルギー群の鼻粘膜酸素分圧に有意差 はなく，また，レーザー手術後に鼻粘膜酸素分圧が増加 する症例，減少する症例まちまちで一定の傾向はなく， 手術前後での有意差もみられなかった.レーザー手術前 後の鼻粘膜血行動態に関しては，友田ら ${ }^{11)}$ は，反射ス ペクトル法を用い鼻粘膜局所へモグロビン量の指標(以 下 IHb)を測定し，術前の鼻アレルギー患者の IHb は正 常者に比し有意に低下していたが，術後は正常レベルま で回復し鼻粘膜血行動態の改善がみられ，病理組織学的 にも術後の鼻粘膜固有層浅層に多数の血管新生が確かめ られた，と報告している。また，川村ら10)はレーザー ドップラー法を用い鼻粘膜表層の血流量を測定し，術前 の鼻アレルギー患者の鼻粘膜血流は正常者に比し有意に 低下していたが，術後はさらに低下傾向を示したとし， 虚血と間質の浮腫により低下した鼻粘膜血流は，レー ザー手術により血管の乏しい瘢痕組織に置換されるため さらに低下したものと考察している．測定対象や測定法 が異なるため一律に比較することはできないが，鼻粘膜 酸素分圧, IHb，鼻粘膜血流量はいずれも鼻粘膜血行動 態を表す指標と考えられる。しかし，今回のわれわれの 
結果とこれら諸家の報告はそれぞれ異なっている。その 理由の 1 つとして, 術後測定時に抢ける鼻粘膜創傷治瘉 状態の個体差が関与しているものと考えられる.すなわ ち，今回われわれが検討した鼻粘膜酸素分圧に関しては， 鼻粘膜固有層が新生血管に富む幼若な肉芽様組織である 症例では術前より増加し，一方で鼻粘膜固有層が血管に 乏しい瘵痕様組織へと变化しつつある症例では術前より 低下しているものと推察される. 鼻粘膜は, 粘膜表面近 くを流れる係蹄状毛細血管と多量の血液を貯える深部洞 様血管, さらに動静脈吻合もみられる解剖学的に特異な 血管構築をして扣り ${ }^{12)}$, その血行動態に関しては, 測定 法, 特に測定深度の違いなどにより未だ一定の見解に達 して抢らず13144)，今後さらなる検討を要するものと思わ れる。

第 5 点として, 鼻粘膜の知覚神経および自律神経が, レーザーの熱作用により変性することがあげられる，こ れにより鼻粘膜の過敏性が低下し，神経を介する鼻症状， 特にくしゃ反発作や水様性鼻汁が軽減するものと考兄ら れる.下甲介化学剤手術を施行した八尾ら ${ }^{15)} は$ は、トリ クロール酢酸による神経伝達機能障害をその作用機序の 1 つにあげている。また, 斎藤16) は, 下鼻甲介電気凝 固術では鼻粘膜神経成分に対する凝固作用により鼻粘膜 過敏性が低下寸る，と指摘している，鼻粘膜固有層には アドレナリン作働性, コリン作働性神経線維が共に豊富 に存在する17)が, レーザー手術においては, 同部を十 分に蒸散・切除するために，化学剤手術や電気凝固術同 様, 鼻粘膜神経線維に対する変性作用を有することが容 易に推察される. 鼻粘膜自律神経系を介寸る反射の元進
とされる血管運動性鼻炎に対してもレーザー手術が有効 である1819)ことは，臨床的にこの点を支持するもので あろう。

以上，鼻アレルギーに対するレーザー手術の作用機序 として，主たるもの 5 点について述べた。これらは，い ずれもレーザー手術のみが持つ特別な機序ではないが， 作用機序といら観点から他の外科的治療法と比較すると, レーザー手術に括いて最も有効かつ総合的に作用するも のと思われる(表 3 ).

2.レーザーの照射法について

鼻アレルギーのレーザー手術は, 下鼻甲介粘膜を蒸散 する方法と，切除する方法に大別される.

下鼻甲介粘膜を蒸散する場合は, 反射率・散乱率が低 く組織吸収率が高い $\mathrm{CO}_{2}$ レーザーを用いることが適し ている. $\mathrm{CO}_{2}$ レーザーの照射条件に関しては，国外で は, Mittelman ${ }^{20)}$ は, $6 \sim 10 \mathrm{~W}$ ，スポットサイズ 1〜2 mmの defocused beam で, Selken ${ }^{21)}$ は, 15〜18 W, 連続波で focused beam と defocused beamを組み合わ せて, Elwany ら ${ }^{22)}$ は 20 30 W, defocused beam で蒸 散している. 国内では, 福武ら ${ }^{9)}$ は $20 \mathrm{~W}, 0.1 \mathrm{sec}$ のパ ルス波, defocused beam で, 窪田ら 23$)$ は, 8 22 w, 0.5 secのパルス波, defocused beam で行っている. 当科に おいても, defocused beamで，出力は $15 \mathrm{~W}$ とほぼ同 等であるが，一度に可及的に広範囲を蒸散するので，手 術時間を短縮させるためにも連続波を用いた，連続波で は熟練を要し誤照射なども懸念されるといら意見24)も あるが, 自験例では, 連続波を用いても臨床上問題とな るような誤照射は皆無であり，また連続波により出血量

表 3 各種外科的治療法の作用機序の比較

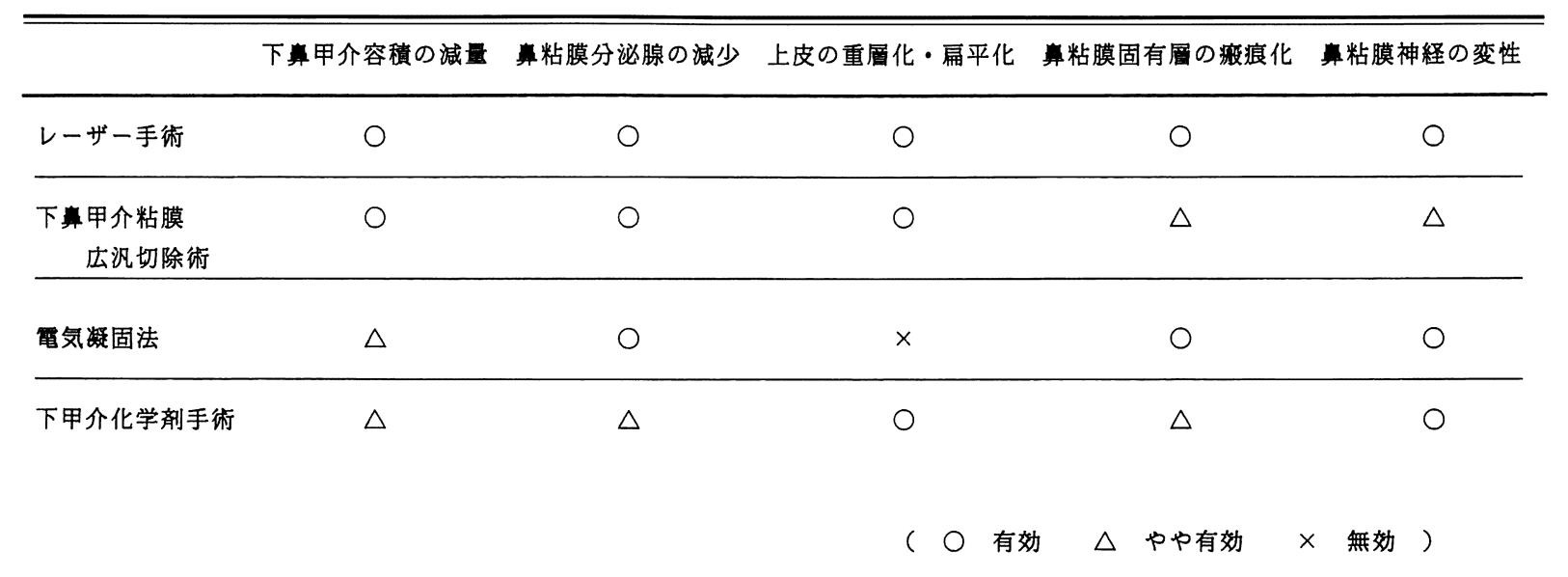


の増加や下鼻甲介骨の壊死を来した症例もなく, 安全か つ簡便に照射することができた．手術回数については， Mittelman'20) および Selken ${ }^{21)}$ は，いずれも 1 回であり， 福武ら 9 は週 1 回の割りで 5 回を 1 クールとして行って いる. 窪田ら ${ }^{23)}$ は，手術回数は $1 \sim 2$ 回ですむ症例が 8 割以上とし, 追加照射の必要性は個々の重症度や術後 改善度により異なることを指摘している。われわれは， 一度に可及的に広範囲を蒸散することにより鼻腔に十分 なスペースが得られるよらに心掛け，1回の手術を原則 とし経過を観察することとしている．分割照射に比べる と, 術後の反応性の鼻閉や鼻汁が $1 \sim 2$ 週とやや遷延す る傾向はあるが，通院回数が少なくてすむといら利点が ある。

下鼻甲介粘膜を切除する場合は，血流に富む組織であ るので凝固能に優れ，狭い術野であるので接触照射可能 でかつ手術器具が細径であるレーザーを用いることが適 している. 従来, 臨床の場ではNd-YAGレーザーが多 用されてきたが，当科では 1 世代新しいKTP/532レー ザーを用いている．このレーザーは，Nd-YAGレーザー 光を KTP (Potassium-Titanyl-Phosphate) 結晶を通して 得られる波長 $532 \mathrm{~nm}$ の緑色可視光で，切開能・凝固能 ともにバランス良く兼ね備えて扣り, 細径の石英ファイ バーで導光され，接触执よび非接触照射が可能である25). 下鼻甲介粘膜を切除する場合の照射条件に関しては，接 触型 Nd-YAG レーザーを用いた古田ら 26) は出力 $10 \mathrm{~W}$, 連続波で行ったと報告している. 今回当科で用いた $\mathrm{KTP} / 532$ レーザーでは，7～10 W の連続波で行ったが， ほとんど出血することなく十分に下鼻甲介粘膜を切除す ることができた。

下鼻甲介粘膜を蒸散する場合も切除する場合も，その 目的は，アレルギー反応の場である鼻粘膜を十分に減量 せしめ，レーザーの持つ熱作用により鼻粘膜を凝固変性 させることにある.その意味では, $\mathrm{CO}_{2}$ レーザー， $\mathrm{KTP} / 532$ レーザーいずれもその目的を達し得るが，後 者の方が，より確実に鼻粘膜を処置することができるも のと思われた。ただし，術後の鼻粘膜創傷治癒に関して は, $\mathrm{CO}_{2}$ レーザーでは $4 \sim 6$ 週間, $\mathrm{KTP} / 532$ レーザー では 8 １0週間を要し, $\mathrm{CO}_{2}$ レーザーに比べ KTP/532 レーザーでは 2 〜 週間遷延する傾向にあった.

3. 他の外科的治療法との比較について

現在行われている鼻アレルギーに対する外科的治療法 は, vidian 神経切断術に代表される鼻粘膜支配自律神経
切断術と，下鼻甲介粘膜に対する手術とに大別される。

前者の vidian 神経切断術は，手術侵襲が小さいとは いえず，涙腺分泌低下，口蓋知覚鈍麻，開口障害などの 合併症の問題も指摘されている27). また，鼻汁やくしゃ みに関しては劇的な効果はあるものの, 経過が長く組織 学的に鼻粘膜固有層の増生がみられるような症例では鼻 閉が完全に消失しない28)，鼻粘膜腫脹の減退には個体差 がある29), などとする報告もみられ, 現在ではこの手術 の適応はかなり限定されたものとなっている16)30).

後者には，下鼻甲介粘膜切除術31)32）をはじめとして，

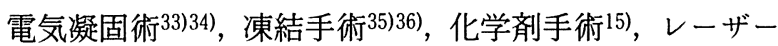
手術20) 22)37) 40) などがある. 施設により異なった術式が 用いられているが，表 4 に示すように，鼻閉に関しては $80 \sim 100 \%$ ，全般改善度に関しては70～90\%とほぼ同等 の短期成績が得られている. しかしながら，下鼻甲介粘 膜切除術は, 出血が多く術後鼻内タンポンも必須で, 多 くの場合入院を要し，小児に扣いては全身麻酔が必要と なり，患者に与える身体的，時間的，経済的負担は多い， 電気凝固術では, 術中かなりの熱感を伴うことが多く, 術後の出血, 痂皮形成さらには下鼻甲介骨壊死なども問 題となる. また, 粘膜下に電極を刺入して行らため, 術 中に術者が肉眼的に凝固したかどうか確かめることがで きない41). 凍結手術では, 約 1 週間持続する術後の高度 な鼻粘膜腫脹が問題であり, また一度に両側の手術を行 5場合, 鼻中隔軟骨壊死や穿孔を起こし得る42). 下甲介 化学剤手術は, 薬剤の深達度が $80 \sim 120 \mu \mathrm{m}^{15)}$ と浅く, 橋口ら ${ }^{43)}$ は, トリクロール酢酸塗布直後の病理組織学 的所見に沶いて，線毛上皮は脱落しても粘膜固有層への 作用は軽微で, 症例によっては術後 $3 \sim 6$ 力月経過する と効果は消失する，と報告している。

レーザー手術に扣いては, 術中の出血・疼痛は皆無で はないが，他療法に比べて軽微であり，術後の鼻内タン ポンは不要で, 外来手術として安全かつ簡便に行らこと ができる．自験例では，対象症例の $22 \%(44 / 204) か ゙ 15$ 歳 以下の小児であり，レーザー手術は，急増する小児鼻了 レルギーに対する一治療法となるらるものと考えている. レーザー手術後 $1 \sim 2$ 週間は, 一過性の反応性鼻閉・鼻 汁が出現するが，それに対する鼻処置や内服薬投与など は必須のものでなく，原則として術後通院も不要である. また, 術後経過中に気道感染症や嗅覚低下などの合併症 をきたした症例もなく，下鼻甲介の骨膜や骨の壊死によ り，いわゆる萎縮性鼻炎のごとく長期にわたり痂皮形成 
表 4 外科的治療成績の比較 (短期成績) 1520021)31) 40)

\begin{tabular}{|c|c|c|c|c|c|c|}
\hline \multirow[t]{2}{*}{ 術 式 } & \multirow[t]{2}{*}{ 報告者 } & \multirow[t]{2}{*}{ 症例数 } & \multicolumn{3}{|c|}{ 症状別有効率 (x) } & \multirow[t]{2}{*}{ 全般改善率 (\%) } \\
\hline & & & くしゃみ & 覍汁 & 宜閉 & \\
\hline \multirow[t]{2}{*}{ 下臭甲介粘膜広汎切除術 } & 高橋ら (1978) & 33 & 56 & 43 & 84 & \\
\hline & 大塚ら (1988) & 68 & 56 & 48 & 93 & \\
\hline \multirow[t]{2}{*}{ 電気疑固法 } & 上田 (1962) & 40 & & & & 87 \\
\hline & 山岨ら (1987) & 55 & & & & 89 \\
\hline \multirow[t]{2}{*}{ 凍結手術 } & Ozenberger (1970) & 46 & & 92 & 100 & \\
\hline & 平出ら $(1980)$ & 13 & 85 & 85 & 70 & \\
\hline 下甲介化学剤手術 & 八尾ら (1988) & 50 & & & 86 & \\
\hline \multirow[t]{7}{*}{ レーザー手術 } & Hittelman(1982) & 30 & & & 100 & \\
\hline & 熊沢ら (1983) & 83 & 77 & 78 & 87 & 88 \\
\hline & Selken(1985) & 34 & & & 100 & \\
\hline & 川村ら (1993) & 365 & & & & 77 \\
\hline & 涳田 (1994) & 121 & 66 & 68 & 92 & \\
\hline & 古田ら (1994) & 100 & 30 & 61 & 100 & 78 \\
\hline & 自験例 & 204 & 70 & 72 & 91 & 87 \\
\hline
\end{tabular}

表 5 外科的治療成績の比較 (長期成績) ${ }^{9332) 38(44) ~ 46) ~}$

\begin{tabular}{|c|c|c|c|c|c|c|c|}
\hline \multirow[t]{2}{*}{ 術 式 } & \multirow[t]{2}{*}{ 報告者 } & \multirow[t]{2}{*}{ 症例数 } & \multicolumn{3}{|c|}{ 症状別有効率 (X) } & \multirow[t]{2}{*}{ 全般改善率 (果) } & \multirow[t]{2}{*}{ 備考 } \\
\hline & & & くしゃみ & 鼾汁 & 鼻閉 & & \\
\hline 下算甲介粘膜広沉切除術 & 大塚ら(1988) & 48 & 30 & 42 & 70 & & 術後 5 年以上アンヶート \\
\hline \multirow[t]{2}{*}{ 電気凝固法 } & 山岨ら (1989) & 30 & 97 & 93 & 100 & & 術後 2 年以上アンヶート \\
\hline & 志井田 (1989) & 100 & & & & 78 & 術後 $1 \sim 9$ 年アンケート \\
\hline 下甲介化学剤手術 & 八尾ら (1993) & 88 & 60 & 50 & 72 & & 術後 3 年以上経過観察 \\
\hline \multirow[t]{3}{*}{ レーザー手術 } & 福武ら(1988) & 40 & & & & 76 & 術後 1 年以上経過観察 \\
\hline & 川村ら (1993) & 45 & & & & 76 & 術後 2 年以上経過観察 \\
\hline & 自験例 & 50 & 80 & 78 & 76 & 76 & 術後 2 年以上アンヶート \\
\hline
\end{tabular}

をみた症例もなかった、レーザー手術は，装置が大掛か りで高価なことが難点であるが，最近では卓上に設置で きる小型で比較的安価なものも開発されており，一般臨 床家に沶いても十分に施行可能な治療法となってきてい る.

4. 長期成績およざ゙再発について

レーザー手術を含めた外科的治療法の長期成績を表 5 に示した.
鼻粘膜広沉切除術を施行した大塚ら ${ }^{32)}$ は, 術後 2 年 まで外来で経過観察したところ鼻閉に対しては $88 \%$ の有 効率が得られたが， 5 年以上経過した 48 症例のアンケー 卜結果ではその改善率は約 $20 \%$ 低下し $70 \%$ 前後であった としている. 電気凝固術により鼻アレルギー治療を施行 した山岨ら ${ }^{44)}$ は, 術後 2 年以上経過した 30 例のアンケー 卜結果に打いて, 術直後に比し若干の増悪傾向がみられ たとし，保存的治療を併用することの重要性を強調した． 
同様に電気凝固術を施行した志井田 ${ }^{45)}$ は, 術後 $1 \sim 9$ 年経過した 100 症例のアンケート調查の結果， $35 \%$ に再 発傾向がみられたと述べている.下甲介化学剤手術を施 行した八尾ら 46) の報告では, 術後 3 年以上経過を観察 した88症例のくしゃみ，鼻汁扣よび鼻閉の改善率はそれ ぞれ60\%，50\%，72\%であった。凍結手術の長期成績に 関する報告は，今回渉猟し得た範囲ではみられなかった。

レーザー手術に関しては, 福武ら ${ }^{9)}$ は, 術後 1 年間経 過を観察した40症例の $15 \%(6 / 40) に 9 \sim 12$ 力月目で再発 が生じたが，全例再手術を行い軽快したと述べ，再発の 原因としては初回照射が不十分であったものと考察して いる. 川村ら ${ }^{38)}$ は, レーザー手術後 2 年以上の長期観 察を行った45例と術後 3 年以上経過する 22 例のアンケー
ト結果より，術後 1 カ月目で有効であれば，ほとんどの 症例でその効果は $2 \sim 3$ 年間は持続するものの, 数\%の 再発例は存在すると報告した。窪田 ${ }^{39)}$ は, 再発は有効 例の約 $30 \%$ にみれるが，内服拉よび追加手術で対処し らるとしている。 また, Mittelman'20) は, 術後 3〜11力 月の経過観察中に $10 \%(3 / 30)$ に再発がみられ，いずれも 不十分な蒸散によるものであろらと考察して扣り， Selkin ${ }^{21)}$ は, 術後 $6 〜 12$ 力月 $21 \%(7 / 34)$ が再発したが, 3 例は再手術により，4例は術前は無効であった抗アレ ルギー㶡の点鼻により軽快したと述べている.

自験例では，短期成績評価時に最も有効率の高かった 鼻閉に関しては，50例中12例の症例 $(24 \%)$ が再発例と考 えられた.これら12例の再発群とレーザー手術の効果が

男性$$
\text { 人 }
$$
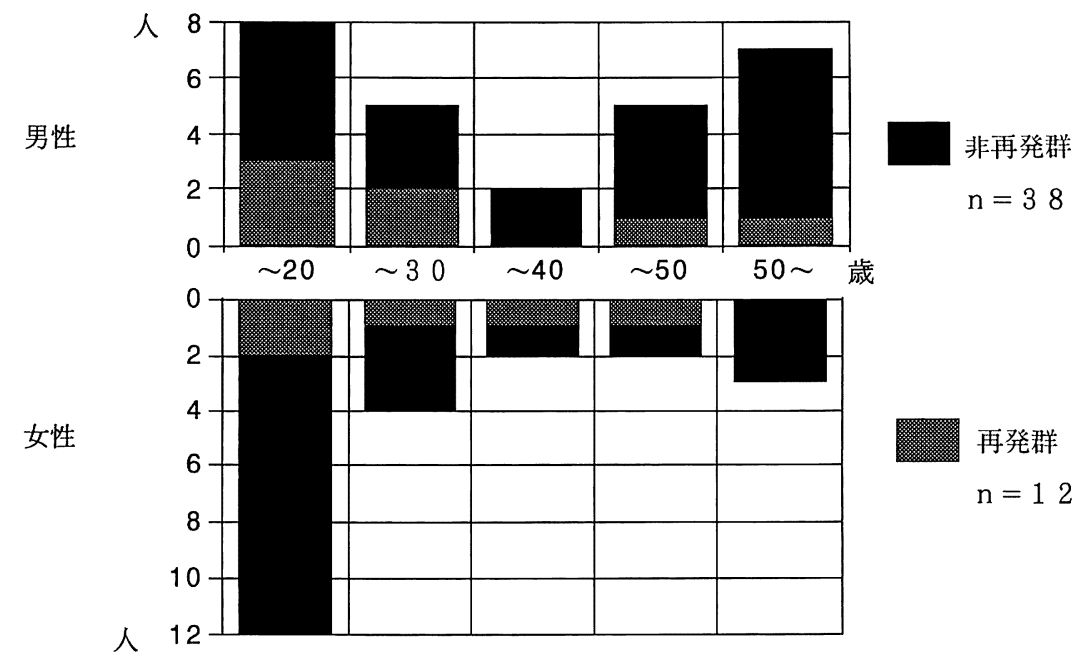

図20長期成績評価群の性別・年齡別構成

性別年歯別構成では両群間に有意差はみられなかった ( $\chi^{2}$ 検定).

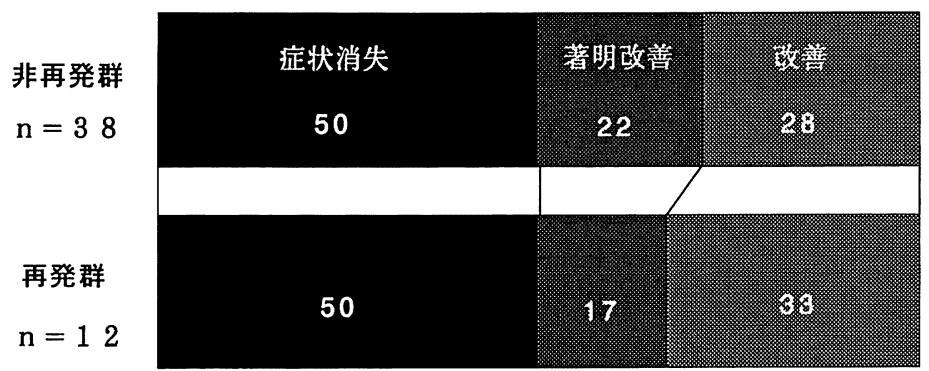

図21短期成績評価時の改善度 短期成績評価時の改善度も両群間に有意差はみられなかった $(\mathrm{H}$ 検 定). 


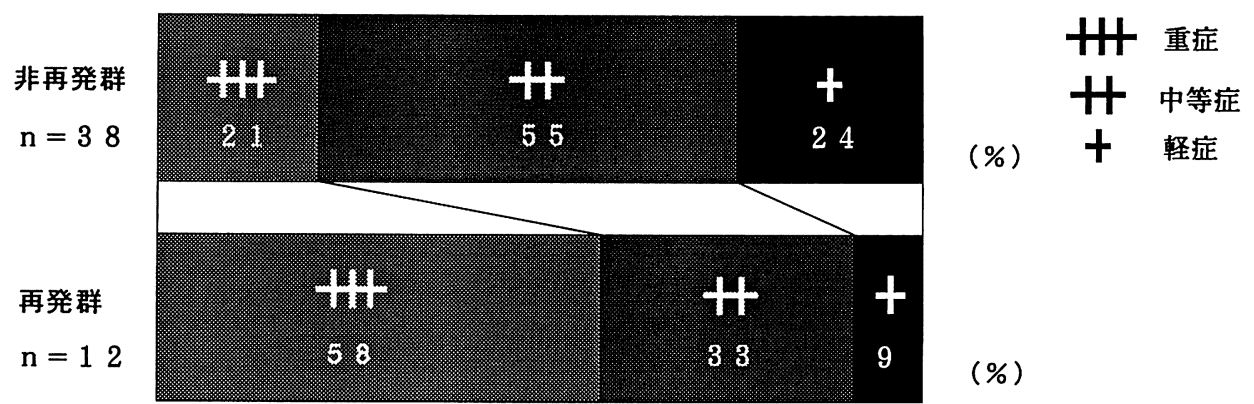

図22術前重症度と再発の有無

再発群に術前重症例が多くみられる傾向があった。

2 年以上の長期にわたり持続していた 38 例の非再発群の 背景因子を比較検討してみた。まず，図20の如く性別・ 年齢別構成では両群間に有意差はみられず ( $\chi^{2}$ 検定), さらに図21の如く短期成績評価時の改善度で比較しても 両群間に有意差はみられなかった( $\mathrm{H}$ 検定)。しかし, 図 22の如く奥田分類による術前の重症度を両群間で比較し てみると有意ではないものの ( $\mathrm{H}$ 検定), 再発群に術前重 症例が多くみられる傾向があった，すなわち自験例では， 鼻閉の再発に関して性・年齢や短期成績との相関はなく， 術前重症例に多くみられる傾向があった. なお, 再発群 12例のらち 5 例は, 再度レーザー手術を行い1994年12月 現在経過良好である。

レーザー手術を含め，外科的治療法は，その長期成績， 言い換えると効果の持続性については未だ不明な点が少 なくない.アンケート調査のみですべてを論ずることに は無理があるが，良性疾患の性質上長期にわたり経過を 観察できる症例は少なく, 今回われわれはアンケート調 查により長期成績を伺い知る一助とした. その結果, レー ザー手術も他の外科的治療法同様, 一部の症例に再発が みられ，鼻アレルギーに対する外科的治療法単独での限 界が示唆された。

下鼻甲介粘膜切除術に特異的減感作療法などの内科的 治療法を併用した大橋ら ${ }^{47)}$ は, 術後 2 力月で手術単独 群の鼻閉の改善率が $81 \%$ であるのに対し, 併用群のそれ は91\%であったと述べている。 また，下鼻甲介粘膜切除 術に抗アレルギー点鼻液を併用した山岸ら ${ }^{48)}$ は, 術後 6 力月で手術単独群のくしゃみ, 鼻汁, 鼻閉の改善率が それぞれ36\%，43\%，87\%であるのに対し，併用群では64 \%，78\%，100\%であった，としている.レーザー手術 に执いても，再発を防止し長期成績を良好なものとする
1 つの方法として, 今後は内科的治療法の併用を考慮し ていく必要があろう.

\section{V. 結 語}

1. 光学顕微鏡扣よび走查型電子顕微鏡を用い, 通年 性鼻アレルギー患者のレーザー手術前後での鼻粘膜の形 態学的变化を観察し，以下の所見をえた.

1 ）術前の患者鼻粘膜には，杯細胞や基底細胞を中心 とした粘膜上皮の増生, 基底膜の肥厚, 扣よび粘膜固有 層の浮腫, 好酸球の浸潤, 鼻粘膜分泌腺の増大, 洞様血 管の拡張などがみられた。

2 ）術後は，扁平上皮化生した形態をとる上皮や立方 ないし円柱状の細胞が重層化した形態をとる上皮で覆わ れていた. 粘膜固有層には, 肉芽様組織もしくは症痕様 組織が認められ, 浮腫, 好酸球浸潤, 増大した鼻粘膜分 泌腺などはほぼ消失していた。

2.レーザー手術による鼻閉の改善度の客観的評価と して, 術前と術後短期成績評価時に鼻腔通気度検査を施 行した。その結果, 術前の鼻腔抵抗値は $0.60 \pm 0.27$ $\mathrm{pascal} / \mathrm{cm}^{3} / \mathrm{sec}$ であり, 術後は $0.30 \pm 0.09 \mathrm{pascal} / \mathrm{cm}^{3}$ $/ \mathrm{sec}$ と有意に減少した $(\mathrm{p}<0.01, \mathrm{t}$ 検定 $)$.

3.レーザー手術による鼻粘膜血行動態の変化につい て検討する目的で，一部の症例において術前と術後短期 成績評価時に鼻粘膜粘膜固有層酸素分圧を測定したが， 有意差はみられなかった。

4. 鼻アレルギーに対するレーザー手術の作用機序と して,

1) 下鼻甲介容積の絶対的な減少

2) 杯細胞拉よび鼻粘膜分泌腺の減少

3 ）鼻粘膜上皮の重層扁平化によるアレルギー反応の 
抑制

4 ）鼻粘膜固有層の肉芽様組織さらには瘢痕様組織へ の置換

5 ）鼻粘膜知覚神経抢よび自律神経の変性 などが考えられた。

5. 1986年 6 月より1993年11月の間, 防衛医科大学校 病院耳鼻咽喉科外来で難治性通年性鼻アレルギー患者 204例に対しレーザー手術を施行し，以下の臨床成績を えた。

1) 短期成績 (術後 $4 \sim 10$ 週) として，〈しゃみに対し ては70\%(119例中83例)に，鼻汁に対しては72\%(166例 中120例)に，鼻閉に対しては91\%(204例中185例)に，全 般改善度では $87 \%$ (204例中177例)に有効であった。特に 鼻閉に関しては，消失 $50 \%$ (204例中102例)，著明改善22 $\%$ (204例中46例) といら極めて良好な成績が得られ，く しゃみ，鼻汁に比べ有意に高い有効率が得られた $(\mathrm{p}<$ $0.01, \mathrm{H}$ 検定).

2 ）術後 2 年以上経過する症例の長期成績として, く しゃみで81\% (32例中26例), 鼻汁で78\% (41例中32例), 鼻閉で76\% (50例中38例)の症例に执いて，短期成績評価 時の効果が持続していた。

6. 以上よりレーザー手術は鼻アレルギーに対する 有用な外科的治療法の 1 つであると考㝋た.

稿を終えるにあたり，終始御懇篤なる御指導ならびに御校閲 を賜った恩師井上鐵三教授に深甚なる謝意を捧げます。また， 終始御指導御協力戴いた北原 哲助教授, 田部哲也博士, 小倉 雅実助手, 唐帆健浩医官をはじめ教室員各位に対し深く感謝致 します.さらに, 御協力戴いた防衛医科大学校中央検査部病理 相田真介博士に深謝いたします。

な怙，本論文の一部は第26回日本鼻科学会(1987年 9 月)，第 28 回日本鼻科学会(1989年10月), 第32回日本鼻科学会(1993年 10月)にて発表した。

\section{参考文献}

1）奥田 稔：鼻アレルギー<第 2 版 $>.266 〜 271$ 頁, 金原出 版, 東京, 1992.

2) Lenz $H:$ Endonasales laserchirurgisches Strahlfuhrungssystem und erste klinische Erfahrungen mit dem Argonlaser bei der Rhinopathia vasomotorica. Laryng Rhinol 56 : 749 755, 1977.

3 ）中之坊学, 井上鐵三 : 鼻アレルギーレーザー治療の長期成 績 一アンケート結果を中心に一。第14回日本レーザー医 学会大会論文集. 133 136頁, 1993.
4) 中之坊学, 唐帆健浩, 田部哲也, 他 : 鼻アレルギーのレー ザー治療. JOHNS $10 ： 748 \sim 753,1994$.

5 ）奥田 稔: 鼻アレルギー<第 2 版 $>.271 〜 274$ 頁, 金原出 版, 東京, 1992 .

6) 且井信郎：鼻腔通気度検查. 日耳鼻専門医通信 $32: 6 \sim 7$, 1992.

7) Clemment PAR : Committee report on standardization of rhinomanometry. Rhinology 22 : 151 155, 1984.

8 ）内藤義弘, 白戸 勝 : 鼻腔通気度の比率表示法 一その正

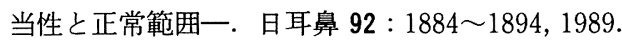

9 ）福武知重, 山下敏夫, 友田幸一, 他: 鼻アレルギーに対す るレーザー手術. 耳鼻臨床 $81: 1163 \sim 1179,1988$.

10）川村繁樹, 久保伸夫, 福武知重, 他: 鼻アレルギーに対す るレーザー手術の検討 一第 3 報 : 効果発現機序の㭲討一. 耳鼻臨床 $86: 815 \sim 821,1993$.

11）友田幸一, 大西純夫, 待木健司：鼻アレルギーに対するレー ザー治療の検討 一鼻粘莫血行動態を中心に一. 耳鼻臨床 $81: 221 \sim 227,1988$.

12）高坂知節：鼻粘膜血管の構築. JOHNS $2: 1049 \sim 1054$, 1986.

13）菊守 寛, 野瀬道宏, 入船盛弘, 他: 大阪大学に批る鼻 アレルギーの現況 一第18報鼻粘膜血行動態の検討一. 耳 鼻臨床 $84:$ 919〜925, 1991.

14）鄭 正舟：鼻アレルギーの鼻粘膜血流動態の観察 ーレー ザードップラー血流計を用いて一。耳展 $37: 168 \sim 176$, 1994.

15）八尾和雄, 設楽哲也, 高橋廣臣, 他: 下甲介化学剤手術 一トリクロール酶酸の応用一. 日耳鼻 $91 ： 1031 \sim 1041$, 1988.

16）斎藤洋三：血管運動性鼻炎, 今日の耳鼻咽喉科頭頸部外科 治療指針 (中井義明, 他編). 251 253頁, 医学書院, 東京, 1992.

17）大前 隆：人下鼻甲介粘膜に批ける自律神経終末の組織化 学的研究. 耳展 補 $4: 425 \sim 451,1984$.

18) Lenz H : Acht Jahre Laserchirurgie an den unteren Nasenmuscheln bei Rhinopathia vasomotorica in Form der Laserstrichkarbonisation. HNO $33:$ 422 425, 1985.

19) Levine HL: The potassium-titanyl phosphate laser for treatment of turbinate dysfunction. Otolaryngol Head Neck Surg $104: 247 \sim 251,1991$.

20) Mittelman $\mathrm{H}: \mathrm{CO}_{2}$ laser turbinectomies for chronic, obstructive rhinitis. Leaser Surg Med 2 : 29 36, 1982.

21) Selkin $S G$ : Laser turbinectomy as an adjunct to rhinoseptoplasty. Arch Otolaryngol $111: 446 \sim 449,1985$.

22) Elwany $S$ and Harrison $R$ : Inferior turbinectomy ; comparison of four techniques. J Laryngol Otol $104: 206 \sim$ 209, 1990

23）漥田市世, 鍋島みどり, 森田 恵, 他: $\mathrm{CO}_{2}$ レーザー下甲 
介手術一その適応と有効性について一. 耳喉頭頸 64： 435〜440, 1992.

24）須藤直廣, 山下敏夫, 熊沢博文, 他 : 鼻アレルギーに対す るレーザーの使用経験. 耳鼻臨床 $76: 869 \sim 875,1983$.

25）井上鐵三, 田部哲也, 小倉雅実, 他 : KTP/532 レーザー の使用経験. 第11回日本レーザー医学会大会論文集. 697 $\sim 700$ 頁, 1990

26）古田茂, 大山 勝, 昇 卓夫, 他 : 鼻内手術へのレーザー 外科の応用. 日鼻科 $26: 251 \sim 256,1988$.

27）佐々木好久, 久松建一 : Vidian Neurectomy の諸問題. 耳 喉 $44: 7 \sim 14,1972$.

28）高橋 良, 堤 昌巳：ヴィディアン神経手術について。耳 展 $13: 719 \sim 725,1970$.

29）戸川 清, 宮下久夫, 藤田洋右, 他 : 鼻アレルギーに対す る翼突管神経切断術について。耳鼻臨床 $64: 1223 \sim 1228$, 1971.

30）奥田 稔：鼻アレルギー<第 2 版 $>$. 293 298頁，金原出 版, 東京, 1992 .

31）高橋光明, 奥田 稔, 打越 進, 他: 鼻アレルギーに対す る下鼻甲介粘膜広汎切除手術. 耳喉 $50: 393 \sim 396,1978$.

32）大塚博邦, 坂口喜清, 渡瀬隆雄, 他 : 鼻粘膜広汎切除術 一遠隔成績について一. 耳喉頭頸 $60: 139 \sim 144,1988$.

33）上田哲二 : 慢性鼻炎の鼻甲介電気弱凝固療法の成績 (第 2 報)。耳喉 $34: 657 \sim 659,1962$.

34）山岨達也, 塩野博巳, 岩沢俊三, 他 : 小児通年性鼻アレル ギーに対する高周波電気凝固療法の検討. 日立医学会誌 $51: 48 \sim 53,1987$.

35) Ozenberger JM : Cryosurgery in chronic rhinitis. Laryngoscope $80: 723 \sim 734,1970$.

36）平出文久, 澤田政道, 井上鐵三, 他 : アレルギー性鼻炎の 凍結手術による治療経験. 鼻副鼻腔 $19: 158 \sim 159,1980$.

37）熊沢博文, 須藤直廣, 三谷武生, 他：鼻アレルギーに対す
るレーザー療法(第 2 報)。日耳鼻 $86: 1255,1983$.

38）川村繁樹, 久保伸夫, 福武知重, 他 : 鼻アレルギーに対す るレーザー手術の検討 一第 1 報 : 効果の持続性の検討一. 耳鼾臨床 $86: 531 \sim 539,1993$.

39）窪田市世：鼻アレルギーに対する下甲介レーザー手術. JOHNS $10: 375 \sim 381,1994$.

40）古田 茂, 出口浩二, 大山 勝：鼻アレルギーに対する物 理療法. JOHNS $10: 389 \sim 392,1994$.

41）五十風睦, 古内一郎：小型電気凝固器とその臨床応用. 耳 喉 $53: 889 \sim 894,1981$.

42) 寺尾 樹, 洲崎春海, 福田 覚: クライオサージェリー。 耳喉頭頸 $60: 545 \sim 552,1988$.

43）橋ロ一弘, 小川浩司: 下甲介トリクロール酢酸塗布療法を めぐって. JOHNS $10: 382 \sim 387,1994$.

44）山岨達也, 岩沢俊三, 福田正弘, 他 : 小览通年性鼻アレル ギーに対する高周波電気凝固療法の検討 一第 2 報, アン ケート調査による遠隔成績一. 日立医学会誌 $53: 45 \sim 49$, 1989.

45）志井田守：高周波電気凝固術と鼻アレルギー。耳喉頭頸 $61: 742 \sim 743,1989$.

46）八尾和雄，設楽哲也：鼻甲介トリクロール酢酸塗布療法. アレルギーの臨床 $13: 680 〜 683,1993$.

47）大橋淑宏, 中井義明：手術療法一下鼻甲介切除術の効果 を上げるには一. JOHNS $7: 764 〜 768,1985$.

48）山岸益夫, 長谷川聡, 中野雄一, 他：鼻アレルギーに扣け る下鼾甲介切除術後のソルフ ${ }^{\circledR}$ 点鼻液の再発予防効果. 耳展 $33:$ 505 512, 1990.

$\left(\begin{array}{l}\text { 原稿受付 : 平成 } 7 \text { 年 } 1 \text { 月 } 26 \text { 日 } \\ \text { 原稿採択 : 平成 } 7 \text { 年 } 3 \text { 月 } 1 \text { 日 } \\ \text { 別刷請求先 : 中之坊 学 } \\ \text { 个359 所沢市並木 } 3-2 \\ \text { 防衛医科大学校耳鼻咽喉科学講座 }\end{array}\right)$

